\title{
Medicínská antropologie jako součást antropologického diskurzu
}

\author{
Václav Soukup \\ Ústav etnologie, Univerzita Karlova, Filozofická fakulta, nám. Jana Palacha 1/2, 11638 Praha 1 \\ Do redakce doručeno 29. ř́ina 2019; k publikaci přijato 24. června 2020
}

\section{MEDICAL ANTHROPOLOGY AS A PART OF ANTHROPOLOGICAL DISCOURSE}

\begin{abstract}
The subject of the study is a theoretic analysis of medical anthropology seen as an independent subdiscipline and a thematic area of anthropologic research. The objective of the study is to chart the main trends in medical anthropology and describe its biocultural nature. Special attention is paid to the relation between medical anthropology and death anthropology in the context of dying and attitude to human death. The study analyses the research potential of medical anthropology from intercultural as well as from evolutionary perspective with emphasis on human body transformations during the Neolithic Revolution.
\end{abstract}

KEY WORDS medical anthropology; culture; human body; health; Neolithic revolution

ABSTRAKT Předmětem studie je teoretická analýza medicínské antropologie jako svébytné subdisciplíny a tematické oblasti antropologických výzkumů. Cílem studie je zmapovat nosné trendy v medicínské antropologii a postihnout její biokulturní charakter. Zvláštní pozornost je věnována vztahu medicínské antropologie a antropologie smrti v kontextu umírání a postoje k lidské smrti. Studie analyzuje výzkumný potenciál medicínské antropologie jak z mezikulturní, tak evoluční perspektivy s důrazem na proměny lidského těla v období neolitické revoluce.

KLÍČOVÁ SLOVA medicínská antropologie; kultura; lidské tělo; zdraví; neolitická revoluce

\section{MEDICÍNSKÁ ANTROPOLOGIE JAKO SUBDISCIPLÍNA A TEMATICKÁ OBLAST ANTROPOLOGICKÝCH VÝZKUMŮ}

Pojem antropologie pochází z řeckých slov anthropos (člověk) a logos (rozum, slovo nauka). Současnou antropologii je možné vymezit jako holistickou, interdisciplinární a komparativní vědu, která se zabývá studiem biologické a kulturní variability lidských populací v čase a prostoru. Charakteristickým rysem současné antropologie je snaha antropologů využívat stále širšího spektra poznatků různých přírodních a společenských věd. Biologické a kulturní antropology v úsilí o integraci různých vědních disciplín spojuje společný předmět jejich výzkumu - člověk. Antropologickou vědou, studující prostřednictvím výzkumů lidského těla biologickou variabilitu lidstva, je fyzická (biologická) antropologie, která se snaží rekonstruovat průběh evoluce lidského rodu nebo pátrat po prŕčinách a důsledcích biologické rozmanitosti lidstva. Antropologickou vědou studující kulturní dimenzi lidského rodu je sociokulturní (sociální a kulturní) antropologie, která zkoumá kulturní rozmanitost lidských společností (Miller Wood 2006; Levinson - Ember 2008; Soukup 2011; Kottak 2007, 2018). Kultura vznikla v průběhu evoluce lidstva jako nadbiologicky vytvořený systém prostředků a mechanismů, jehož prostřednictvím se lidé adaptují k prrírodnímu a sociálnímu prostředí. Konkrétní kulturní systémy zahrnují materiální produkty cílevědomé lidské práce (artefakty), sociokulturní regulativy (obyčeje, mravy, zákony, tabu) a ideje (kognitivní a symbolické systémy), které jsou sdíleny a předávány příslušníky určité společnosti (Soukup 2011).

Rysem současné antropologie je diferenciace antropologických subdisciplín a tematických oblastí antropologického 
výzkumu. Narůstající specializace konkrétních antropologických disciplín představuje logický důsledek snahy antropologů studovat člověka, společnost a kulturu z nejrůznějších zorných úhlů. Nesmírná šíre předmětu antropologických výzkumů tak vedla ke konstituování stále více „specializovaných antropologii“" které kladou důraz na studium velmi širokého spektra různých oblastí lidské činnosti. Jsou-li součástí lidské kultury víra, právo, politika, ekonomika, umění a př́íbuzenské systémy, je logické, že existují takové antropologické subdisciplíny, jako jsou antropologie náboženství, antropologie práva, politická antropologie, ekonomická antropologie, antropologie umění a antropologie př́buzenských systémů. Logickou součástí antropologických výzkumů byl také vždy zájem o lidské tělo a problémy spojené s péčí o zdraví a léčbou nemocí. Biokulturní orientace antropologie se tak projevila rozvojem výzkumů, které dnes označujeme jako medicínskou antropologii. ${ }^{1}$

Za ideové zdroje medicínské antropologie je možné označit antropologické výzkumy evoluce a adaptace, etnografické výzkumy orientované na nativní medicínské praktiky, studium etnopsychiatrických jevů $\mathrm{v}$ transkulturní perspektivě a antropologické práce věnované mezinárodnímu zdravotnictví (Brieger 2004). Při studiu medicínských znalostí a postupů mimoevropských kultur antropologové registrovali nejen existenci svébytných „etnomedicín“ a nativních klasifikačních soustav domorodých nemocí, ale také jejich sepětí s místní magií, rituály, čarodějnictvím a náboženstvím (Evans-Pritchard 1937; Waldstein - Adams 2006). Pojem etnomedicína sloužil k označení komparativního studia lékařských systémů $\mathrm{s}$ důrazem na nativní př́stup $\mathrm{k}$ nemocem a jejich léčbě. $\mathrm{V}$ ohnisku výzkumu se tak postupně ocitly léčebné praktiky a postoje $\mathrm{k}$ nemoci $\mathrm{v}$ různých kulturách světa. Západní biomedicína začala být vnímána pouze jako jeden $\mathrm{z}$ mnoha možných přístupů $\mathrm{k}$ lidskému zdraví a mohla být jako lékařský systém transkulturně srovnávána s odlišnými nativními medicinskými systémy. V 50. a 60 . letech 20 . století postupně narůstal zájem antropologů o rodící se medicínskou antropologii zejména v souvislosti s praktickým řešením zdravotních problémů obyvatel zemí třetího světa. Zvyšoval se i počet teoretických i empirických studií věnovaných transkulturnímu studiu nezápadních medicínských systémů, které byly vnímány jako svébytné kognitivní a symbolické systémy. Medicínská antropologie v tomto období interdisciplinárně oscilovala na hranici medicíny a obecné antropologie (Foster - Gallatin Anderson 1978; Helman 2001; Lupton 1994). V průběhu 70. let se pod vlivem symbolické a interpretativní antropologie medicínští antropologové věnovali ve stále větší míře analýze etnomedicínských systémů. $\mathrm{V}$ ohnisku jejich výzkumného zájmu se ocitla zejména problematika medicínské epistemologie, etnovědy a etnosémantiky. Lékař, pacient a jeho onemocnění byla zkoumána $\mathrm{z}$ emické perspektivy jako sít symbolů a významů, které musí být dekódovány a interpretovány v kontextu dané kultury. V 70. letech došlo ve Spojených stá-

1 Vedle pojmu medicínská antropologie jsou používány také alternativní označení lékařská antropologie, antropologie zdraví nebo antropologie nemoci. tech amerických k institucionalizaci medicínské antropologie. Pod záštitou American Anthropological Association vznikla Society of Medical Anthropology, v jejímž čele stanula psychiatrička Dorothea Cross Leightonová. Ta se zapojila do projektu, který měl podpořit stav zdravotnického systému indiánů kmene Navajo (Navajo Health Project).

V 80. letech antropologové obrátili svoji pozornost ke studiu subkultur a sociokulturních jevů existujících uvnitř západní společnosti. Tento obrat, označovaný jako „anthropology at home“, se promítl do zvýšeného zájmu o výzkum západní biomedicíny jako produktu širších ekonomických, politických, sociálních a globálních procesů. Od 90. let je již možné mluvit o expanzi medicínské antropologie, která stále více ovlivňovala a dodnes ovlivňuje formování alternativních antropologických teorií věnovaných lidské tělesnosti a výzkumu nových lékařských technologií, včetně jejich dopadu na lidské zdraví (Joralemon 2017; Singer - Baer - Long - Pavlotski 2019).

Současná medicínská antropologie představuje dynamicky se rozvíjející biokulturní antropologickou subdisciplínu, která programově využívá poznatky a metody fyzické antropologie, sociokulturní antropologie, antropologické archeologie a lingvistické antropologie. Jedná se o tematickou oblast antropologických výzkumů biologických a kulturních aspektů lidského chování a prožívání, které ovlivňují lidské zdraví, nemoc a zdravotní péči. ${ }^{2}$ Předmětem medicínské antropologie je jak studium zdravotních problémů lidí, tak holisticky a komparativně koncipovaný výzkum zdravotních systémů $\mathrm{v}$ širokých sociokulturních kontextech. Zvláštní pozornost je věnována biokulturním a ekologickým faktorům, které ovlivňují lidské zdraví, kvalitu života, vznik a šíření nemocí, jejich prevenci a léčbu, včetně využití alternativních medicínských systémů. Základním rysem medicínské antropologie je snaha popsat, analyzovat a interpretovat péči o lidské zdraví v širších historických, ekologických, sociálních, ekonomických, náboženských a politických souvislostech. Proto medicínští antropologové ve svých výzkumech věnují pozornost širokému spektru faktorů, které ovlivňují lidské zdraví a kvalitu života - životnímu prostředí, sociálním vztahům, sociokulturním institucím, sdíleným hodnotám, normám a idejím, procesům sociokulturní změny a vlivu globalizace, modernizace a ekonomické integrace na proměny současného světa. Mezi preferovaná výzkumná témata medicínské antropologie patři například problematika narození, stárnutí, biokulturní adaptace, systémů zdravotní péče, výživy, infekčních onemocnění, duševního zdraví, globálních epidemií, sexuálních poruch nebo lékařské pomoci v průběhu katastrof (Singer - Erickson 2015). Aplika-

2 Zdraví lze vymezit jako stav tělesné, psychické a sociální funkčnosti organismu, který není limitován nemocí. V západní biomedicíně je vznik nemocí připisován objektivním negativním faktorům, jako jsou mikroorganismy, organické poruchy, zranění, podvýživa atd. V tradičních domorodých kulturách byla onemocnění spojována s působením nadpozemských sil, jako jsou démoni, duchové nebo čarodějové. Vznik nemoci lze ale také interpretovat jako důsledek silného emotivního zážitku nebo psychických traumat. 


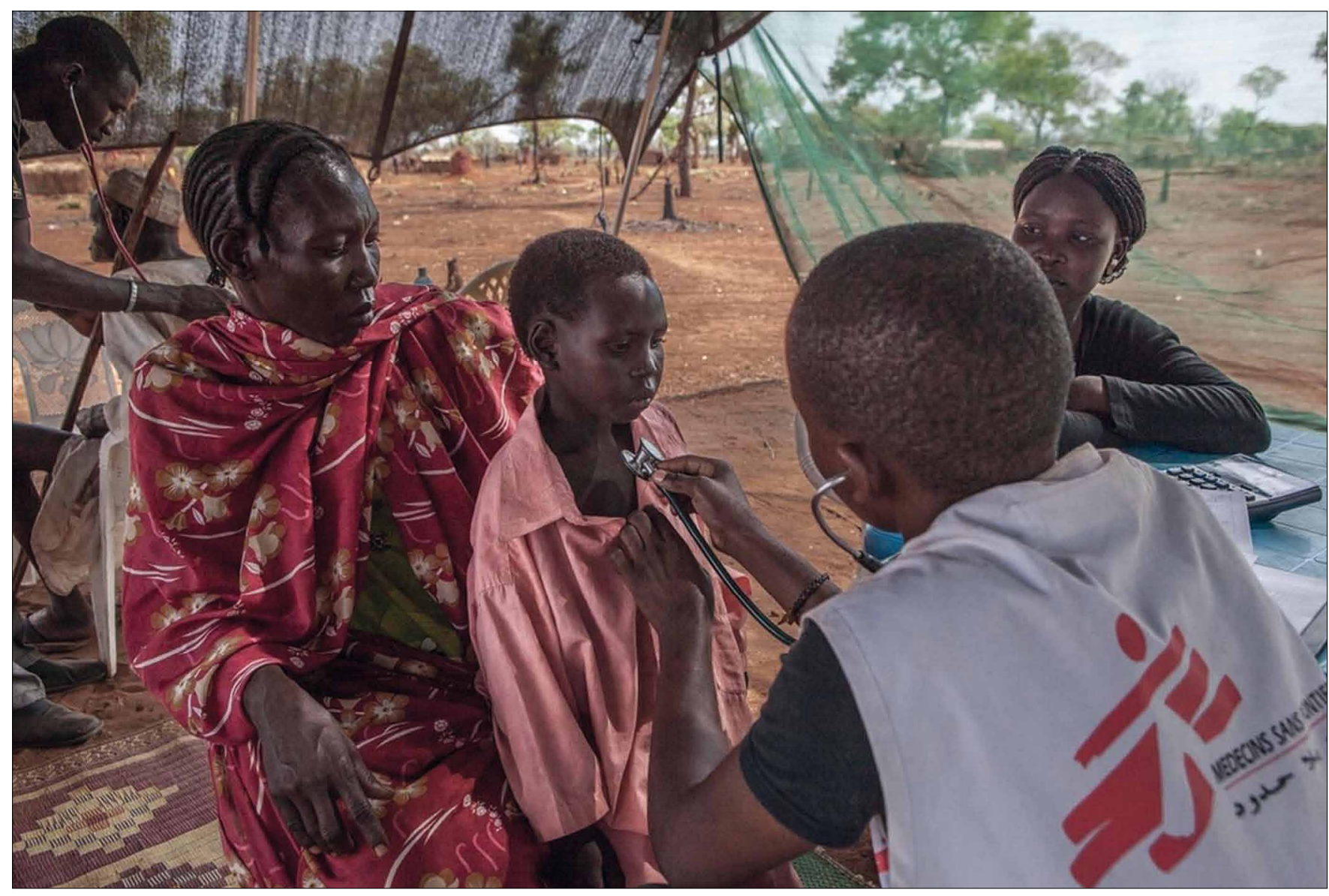

Aplikovaní antropologové se aktivně zapojují do činnosti mezinárodních humanitárních organizací, jako je např́klad Lékaři bez hranic (Médecins Sans Frontières). ( ) Lékaři bez hranic.

ce antropologické doktríny kulturního relativismu na problematiku kulturních reprezentací zdraví, nemocí a lékařské péče umožnila hlubší zamyšlení nad vlivem kultury na to, co daná společnost považuje za normální, deviantní nebo abnormální a přispěla k ověření univerzální platnosti kategorií západní biomedicíny $\mathrm{v}$ odlišných kulturách. $\mathrm{V}$ ohnisku zájmu medicínských antropologů se ocitl také výzkum genotypových a fenotypových faktorů na psychosomatické rysy osobnosti. Medicínská antropologie nesporně přispěla $\mathrm{k}$ rozvoji výzkumů kvality lidského života v kontextu klasických biomedicínských postupů nebo prosazení dlouhodobých léčebných strategií, které se odlišují od invazivních lékařských postupů. Zvýšnou pozornost věnuje také problémům spjatým s implementací západní biomedicíny do kulturních komunit „těch druhých“ a realizaci empirických výzkumů umožňujících pochopit, jak ve vyspělých zemích pacienti a jejich sociální sítě přijímají poznatky o zdraví a nemoci v kontextu vlivu médií, informačních technologií a reklamy. Je také evidentní, že komparativní výzkum systémů lékařské péče a vlivu environmentálních, biologických a sociokulturních faktorů na lidské zdraví bude stále se rozšiřující oblastí antropologických výzkumů. Ústředním tématem medicínské antropologie ale i nadále bude vztah pacienta a lékaře $v$ širším ekologickém a biokulturním kontextu.
Vzhledem k tomu, že kategorie zdraví a nemoc představují významná „kulturní témata“ každé lidské společnosti, výzkum těchto oblastí lidského života umožňuje proniknout jak ke „kulturnímu jádru“ zkoumaných kultur, tak k širším sociálním strukturám, které s péčí o lidské zdraví souvisí. Konkrétní systémy zdravotní péče $\mathrm{z}$ tohoto hlediska představují „mikrokosmos“ každé společnosti, který je neoddělitelnou součástí širšího sociokulturního „makrokosmu“ složeného ze širokého spektra ekonomických, sociálních, politických a ideologických vztahů (Helman 2001; Hrešanová 2008; Brown Closser 2016). Kultura tak vystupuje jako významná determinanta lidského zdraví a lékařské praktiky včetně tzv. „health behaviour“ jsou v ní hluboce zakořeněné (Winkelman 2009). Charakteristickým rysem medicínské antropologie je tak nastolit pluralismus prístupů ke studiu zdraví, nemoci a jejích reprezentací z interkulturní perspektivy.

Snaha medicínských antropologů porozumět prostřednictvím výzkumu mikrosociálního „světa zdravotní péče“ širším globálním makrosociálním procesům, se promítla do konstituování tzv. kritické medicínské antropologie, která dnes představuje jeden $\mathrm{z}$ nosných trendů současných antropologických výzkumů. Reprezentanti kritické medicínské antropologie se snaží poukázat na skutečnost, že vznik a šíření nemocí, jako jsou například HIV/AIDS nebo nové formy tuberkulózy, 


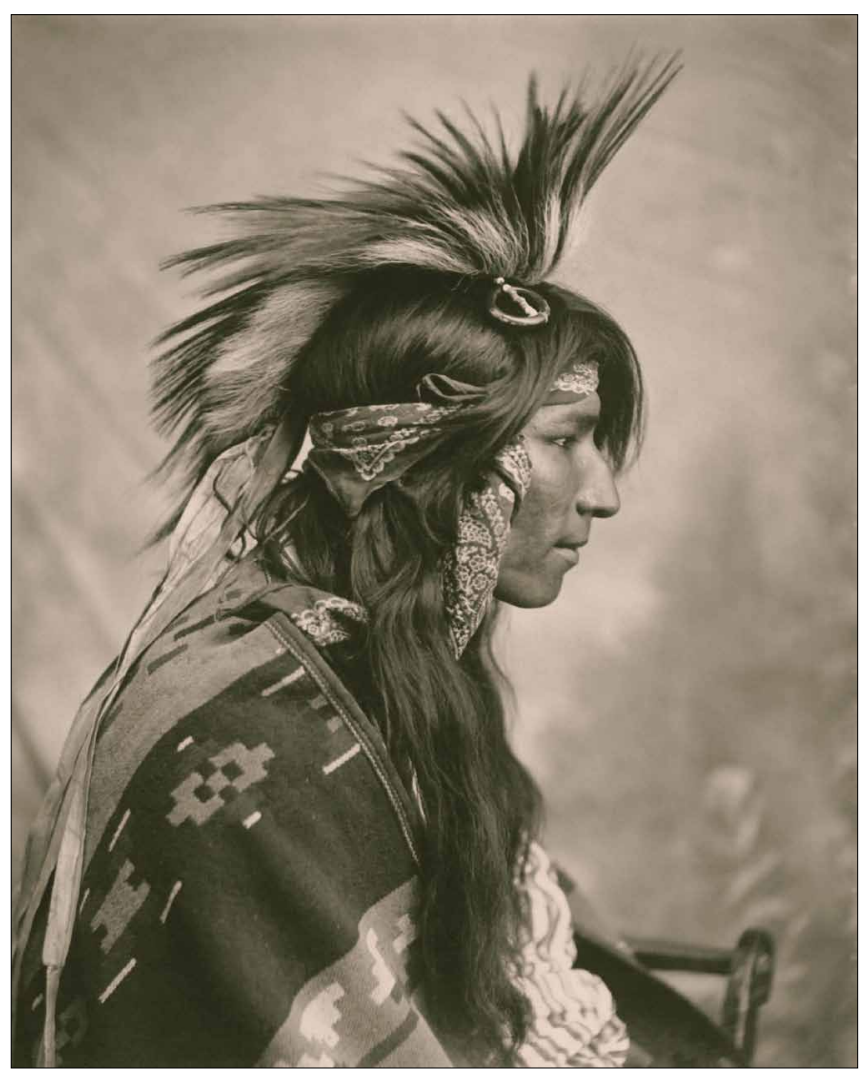

Specifickou součástí studia medicínských folktaxonomií jsou tzv. kulturně specifické syndromy („culture-bound syndroms“), jejichž projevy se vyskytují pouze v jedné kultuře nebo jsou spjaté jen s omezeným množstvím kultur. Jedná se např́klad o psychózu Windigo postihující indiány kmene Krí. (C) British Library.

často souvisí s politickými faktory, ekonomickou nerovností, sociální nespravedlností, chudobou, nerovnými genderovými př́ležitostmi, násilím nebo dokonce genocidou. Takto orientované výzkumy často překračují křehké hranice teoretické antropologie a nachází své uplatnění v medicínsky orientované aplikované antropologii. Je pravděpodobné, že současná celosvětová pandemie způsobená šířením koronaviru, představuje výzvu nejen pro biomedicínu, lékaře, ošetřující personál a zdravotní instituce, ale také pro aplikovaně orientované medicínské antropology. Jedná se totiž o globální biokulturní problém, který neovlivňuje pouze zdraví lidí, ale také způsob života a fungování širokého spektra institucí $\mathrm{v}$ postižených zemích. Epidemie koronaviru narušila volný pohyb lidí, distribuci surovin, zboží i služeb. Tím ovlivnila fungování ekonomických, sociálních, politických, zdravotních i vzdělávacích systémů. Vtiskla novou podobu mechanismům sociální kontroly a zdravotní prevence. $\mathrm{V}$ celé řadě odvětví způsobila pokles zaměstnanosti, což má negativní vliv na životní úroveň a kvalitu života mnoha milionů lidí. Vznik, průběh a důsledky šíření koronaviru navíc různým způsobem ovlivnily osudy lidských společností z transkulturní perspektivy, nebot’ vyvolaly odlišné reakce v kulturně odlišných zemích. Proto by bylo užitečné provést z perspektivy medicínské antropologie mezikulturní komparativní analýzu úspěšnosti opatření, která konkrétní státy v boji s koronavirem přijaly. $\mathrm{V}$ souladu s cíli medicínské antropologie by se tak další aktuální oblastí aplikovaného antropologického výzkumu stala deskripce a analýza vlivu koronaviru na lidské zdraví, systémy zdravotní péče a způsob života př́slušníků různých kultur. Zvláštní pozornost by přitom měla být věnována sociokulturním, biologickým a zdravotním důsledkům šíření koronaviru jako faktoru a determinanty endogenní a exogenní sociokulturní změny. Již v současné době je totiž zřejmé, že epidemie koronaviru proměňuje jak vnitřní strukturu a fungování konkrétních sociokulturních systémů, ${ }^{3}$ tak jejich vzájemnou interakci.

Jak již bylo konstatováno, medicínská antropologie je jak teoretickou, tak aplikovanou antropologickou disciplínou (Good 1994; Singer, Baer 2011; Hrešanová 2008; Singer - Erickson 2015). Na jedné straně přispívá $\mathrm{k}$ hlubšímu pochopení fungování sociokulturních systémů $\mathrm{z}$ perspektivy péče o lidské zdraví, na straně druhé využívá získané poznatky $\mathrm{k}$ řízení procesů sociokulturní změny s cílem zkvalitnit stávající systémy zdravotní péče. Aplikovaná medicínská antropologie programově usiluje o řešení problémů souvisících s onemocněním, jeho léčbou a lidským zdravím. Proto se aplikovaní antropologové aktivně zapojují do činnosti mezinárodních humanitárních organizací, jako jsou Světová zdravotnická organizace (WHO), UNICEF nebo Lékaři bez hranic (Médecins Sans Frontières). Často také přijímají roli učitelů, poradců, expertů či členů interdisciplinárních týmů, které pomáhají řešit komplexní problémy spjaté s vlivem ekologických, demografických, ekonomických a technologických faktorů na lidské zdraví. Z tohoto hlediska mají úzkou vazbu na klinickou antropologii, jež se zabývá praktickým poskytováním péče pacientům umístěným ve zdravotních zařízeních, a na disciplínu označovanou jako „public health“, která se věnuje řešení tíživých zdravotních problémů obyvatel rozvojových zemí (Helman 2001). Velký potenciál aplikované medicínské antropologie spočívá také $\mathrm{v}$ tom, že její reprezentanti dokážou zasazovat lokální lékařské problémy do širšího kulturního kontextu a disponují znalostmi a dovednostmi $z$ oblasti interkulturní komunikace.

Aplikovaná medicínská antropologie jako disciplína usilující o prosazování změn v oblasti péče o zdraví a fungování zdravotních systémů, může mít v reálné praxi různou podobu. Podle Merrill Singera lze mluvit minimálně o dvou základních typech aplikovaného výzkumu. První z nich, označovaný jako „praxe korigující systém“, neaspiruje na zásadní proměnu základní struktury sociálních vztahů a transformaci systému zdravotní péče, ale provádí pouze jeho drobná „kosmetická“ zlepšení. Druhý typ, označovaný jako „praxe zpochybňující systém“, je ve svých důsledcích mnohem razantnější, nebot' usiluje o trvalou transformaci systému s cílem „demaskovat původ sociální nerovnosti“ (Singer 1995, 90). Podle reprezentantů kritické medicínské antropologie se př́istup zpochybňu-

3 Pojem sociokulturní systém je $\mathrm{v}$ antropologii používán jako označení systému vzájemně spjatých artefaktů, sociokulturních regulativů a idejí, které jsou sdíleny příslušníky určité společnosti. 


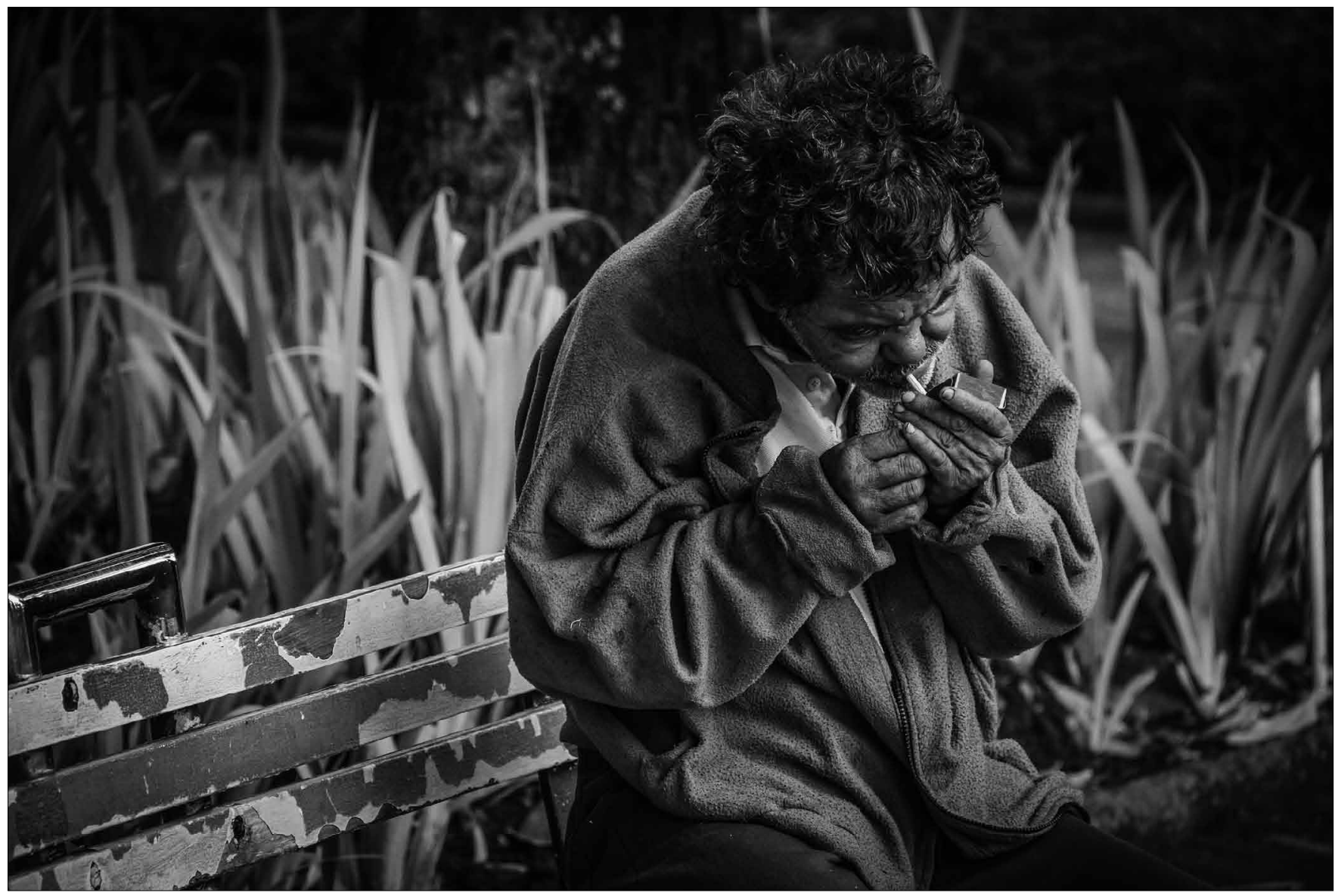

Koncept strukturálního utrpení odkazuje na skutečnost, že nemoc není ryze individuální záležitostí, ale souvisí se sociálními, politickými a ekonomickými podmínkami, které limitují zdraví člověka. V ohnisku výzkumů medicínských antropologů se tak ocitly faktory ovlivňujíć lidské zdraví, jako je chudoba. @ Pexels.

jící systém může stát „mocnou zbraní, která umožní odhalit negativní dopady ekonomických, politických a sociálních problémů na lidské zdraví.

Jedním z velkých př́nosů medicínské antropologie je, že upozornila na gnozeologické limity západní biomedicíny, která byla po dlouhá staletí považovaná za jediný adekvátní, racionální a profesionální přístup k léčbě nemocí. Pojmem biomedicína je označován systém lékařských znalostí a dovedností, který vznikl v průběhu vývoje západní civilizace. Základním axiomem biomedicíny je předpoklad, že nemoc představuje stav organismu, který má biologické příčiny, přičemž léčba by měla směřovat k odstranění těchto příčin (Hahn 1999, 367). Konstituování biomedicíny je ale bohužel spjato s evropocentrickým pocitem nadřazenosti nad etnomedicínou preliterárních společností i alternativními medicínskými systémy nezápadních národů a kultur. Západní medicína jako specifický diskurs v sobě také obsahuje pečet’ redukcionismu, nebot má tendenci oddělovat biologické aspekty nemoci od širších sociokulturních a psychosomatických souvislostí. Přesto je dnes biomedicína nejvíce rozšířeným lékařským systémem a je oprávněně označována za globální nebo kosmopolitní medicínu (Miller - Wood 2006). Distribuce západní biomedicíny do různých zemí světa ale vedla $\mathrm{k}$ její transformaci do podo- by pluralitních lékařských systémů, které vykazují celou řadu specifik. V současné době je proto správnější hovořit o stále více se diferencujícím světě biomedicín (Helman 2001).

$\mathrm{Z}$ metodologického hlediska lze vidět přínos medicínské antropologie v tom, že do výzkumů nemocí zavedla doktrínu kulturního relativismu a perspektivu tzv. etické a emické deskripce sociokulturních jevů. V antropologických výzkumech pojem etická (vnější) deskripce reprezentuje úhel pohledu západního antropologa, který usiluje o objektivní popis a analýzu zkoumané kultury prostrednictvím svých pojmů, taxonomií a zvoleného vědeckého paradigmatu. Oproti tomu emická (vnitřní) deskripce reprezentuje úhel pohledu zkoumaného domorodce, který svoji kulturu popisuje v nativních pojmech a folktaxonomiích (Pike 1967). Dichotomii etického a emického prŕstupu ke studiu medicínských systémů výstižně ilustrují pojmy biomedicína (systém poznatků a dovedností západních lékařů) a etnomedicína (systém poznatků a dovedností domorodých léčitelů). Komplementaritu etického a emického prrístupu ke konceptualizaci nemoci vyjadřují v medicínské antropologii anglické pojmy „disease“ a „illness“. Termín disease reprezentuje etickou perspektivu neboli hledisko „objektivní a „univerzálni“" medicínské vědy, která nemoc vnímá a diagnostikuje jako prrípad reálné a objektivní 

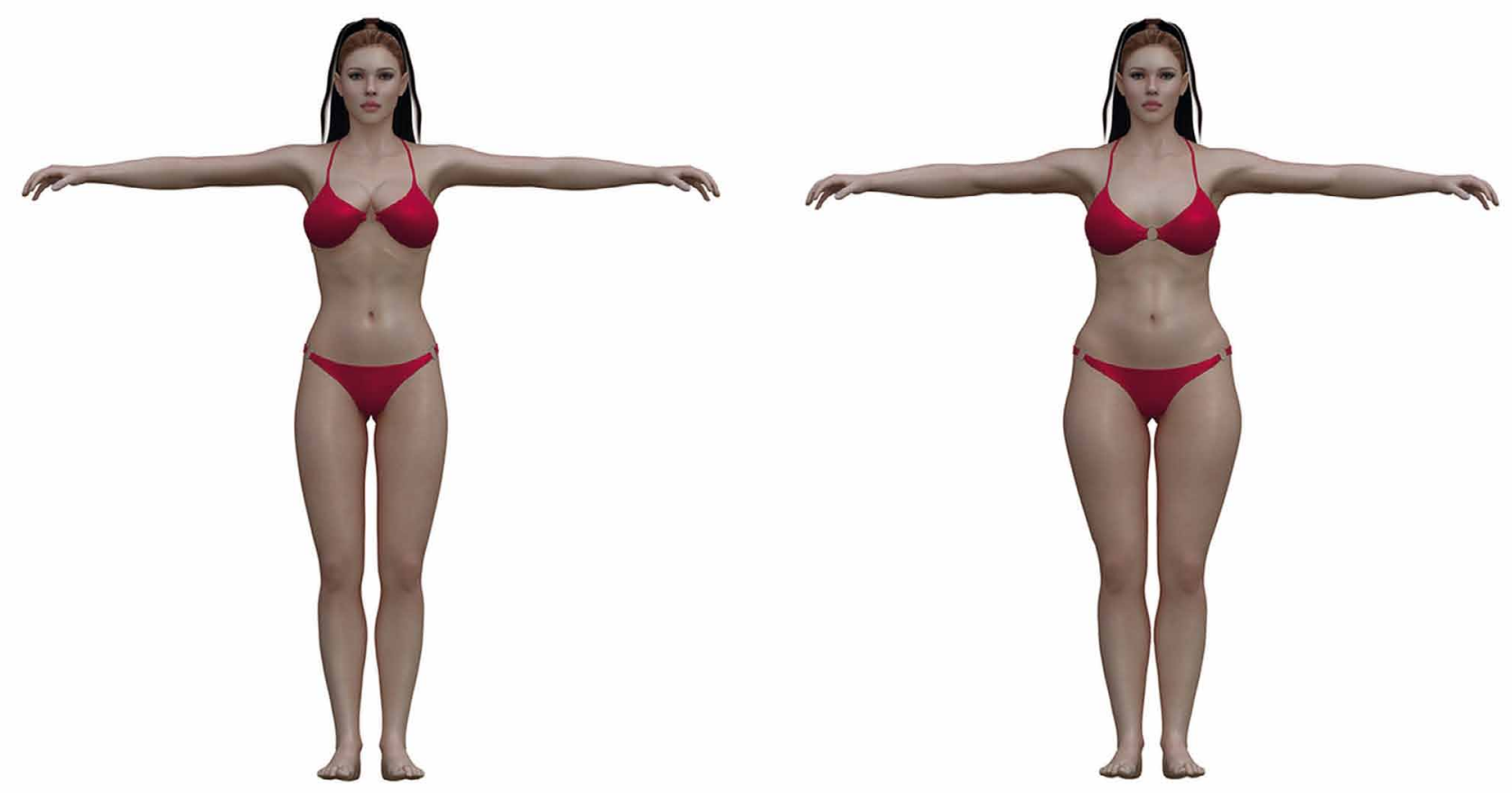

Jako příklad medikalizace je kulturní stereotypizace představ o ideální a žádoucí postavě mladé dívky, která může vyvolat řadu ženských zdravotních problémů. (C) Today Show.

patologie lidského organismu. Tento př́stup je obsažen v širokém spektru diagnostických př́ruček, které se zabývají diferenciální diagnostikou lidských chorob. Oproti tomu, termín illness, který reprezentuje emickou perspektivu pacienta, odkazuje k subjektivně prožívané a vnímané nemoci, která jako sociokulturně podmíněná kategorie nabývá v různých kulturách nejrůznější podoby (Good 1977; Kleinman 1978, 2020; Nettleton 2006). Je zřejmé, že kultura vytváří prostor, „V jehož rámci se nemoci ve smyslu disease i další formy utrpení stávají nemocemi ve smyslu illness" (Miller - Wood 2006, 386). V souvislosti s uplatněním emické perspektivy a aplikací kategorie illness jako gnozeologického nástroje umožňujícího pochopit kulturně podmíněné postoje, pocity a stavy nemocného člověka, se v rámci medicínské antropologie prosadil pojem etnonosologie, který odkazuje k transkulturnímu výzkumu nativních systémů klasifikace zdravotních problémů a nemocí (Miller - Wood 2006, 386). Specifickou součástí studia medicínských folktaxonomií jsou tzv. kulturně specifické syndromy („culture-bound syndroms“), jejichž projevy se vyskytují pouze $\mathrm{v}$ jedné kultuře nebo jsou spjaté jen s omezeným množstvím kultur (Miller - Wood, 387). Jedná se např́klad o polární hysterii, se kterou se můžeme setkat mezi Inuity, psy-

4 Kromě klíčových kategorií disease a illness se můžeme setkat i s pojmem „sickness“, který je použiván k popisu a analýze sociokulturní reakce společnosti na nemoc. Významná je také kategorie „disability“ (nezpůsobilost), jejímž prostřednictvím je vymezeno jakékoliv zdravotní omezení, jež je vnímáno danou komunitou jako fyzická anomálie. chózu Windigo postihující indiány kmenů Krí a Odžibvej nebo onemocnění označované jako aiyiperi, které postihuje př́slušníky kmene Yoruba v Nigérii. ${ }^{5}$

Za významný pojem medicínské antropologie je možné označit také kategorii strukturální utrpení („structural suffering“'). Tento koncept odráží ústř̌ední ideu medicínské antropologie, totiž předpoklad, že lidská onemocnění a s nimi související systémy zdravotní péče, je nezbytné zkoumat v širším historickém a sociokulturním kontextu. Koncept strukturálního utrpení odkazuje na skutečnost, že nemoc není ryze individuální záležitostí, ale souvisí se sociálními, politickými a ekonomickými podmínkami, které limitují zdraví člověka. $\mathrm{V}$ ohnisku výzkumů medicínských antropologů se tak ocitly takové faktory ovlivňující lidské zdraví, jako jsou války, hladomory, chudoba nebo nucená migrace (Miller - Wood 2006, 386).

Aspirace moderní medicínské antropologie rozšírit svoji působnost na analýzu stále širšího spektra jevů a procesů, které původně vưbec nebyly zahrnovány do oblasti medicíny, vyjadřuje také pojem medikalizace (Conrad - Schneider

5 Mezi charakteristické symptomy polární hysterie patři projevy deprese, introvertní mlčenlivost a stavy melancholie, které jsou doprovázeny náhlými záchvaty, při nichž se postižený v křečích válí po sněhu a vydává exaktické výkřiky. Pro psychózu Windigo je typická nechut k obvykle preferovaným jídlům, sklony $\mathrm{k}$ depresi a obavy z kanibalismu, které někdy doprovází sebevražedné sklony. Pro syndrom aiyiperi jsou charakteristické hysterické křečovité poruchy a psychomotorické záchvaty. 


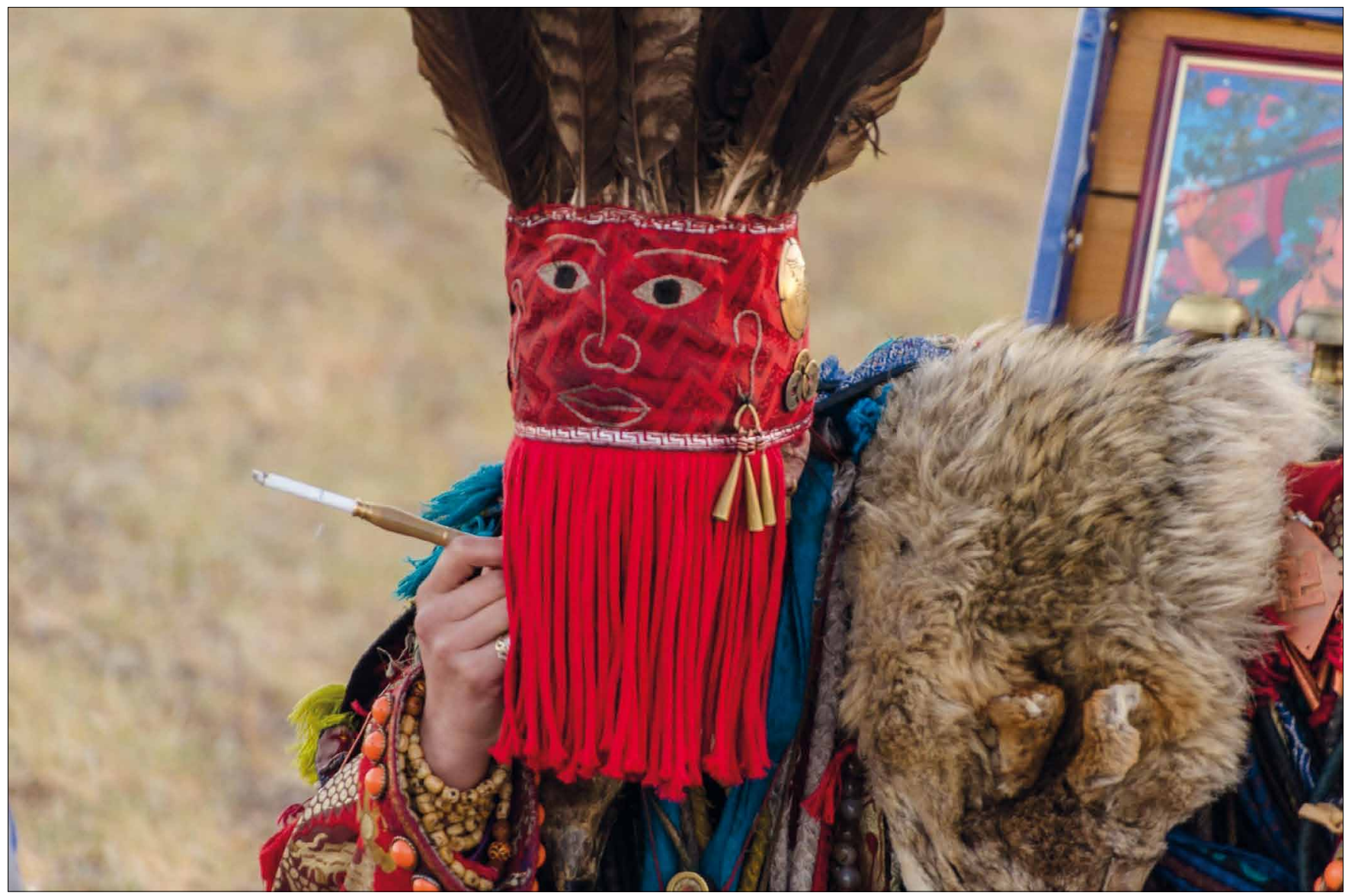

V jednoduchých domorodých společnostech byla etnomedicína často spojena s širšími symbolickými systémy, jako jsou magie a náboženství. Léčiteli zde byli např́ílad šamani, kteří ke stanovení diagnózy využívali komunikaci s duchovním světem prostřednictvím transu a dalších spirituálních praktik. @ Lynn Doran.

1980; Hrešanová 2008). V ohnisku zájmu medicínské antropologie se totiž ocitly oblasti každodenního života, které jsou svojí podstatou spíše sociální povahy, ale přesto ovlivňují lidské zdraví a kvalitu života, a proto vyžadují nastolení medicínské perspektivy, stanovení lékařské diagnózy a uplatnění adekvátní zdravotní péče. Jako př́klad medikalizace může být uvedena kulturní stereotypizace představ o ideální a žádoucí postavě mladé dívky, která může (a vyvolává) řadu ženských zdravotních problémů spjatých s dietními praktikami ohrožujícími lidské zdraví.

Medikalizována byla také řada „normálních“ fyziologických procesů probíhajících v ženském organismu jako jsou menopauza, premenstruační syndrom anebo poporodní psychóza. Na zdravotní projevy tohoto typu zdravotních problémů se totiž nepodílí pouze hormonální změny probíhající v ženském organismu, ale také celá řada faktorů sociokulturní povahy (Miles 1991; Lock 1994). Medikalizace se ale netýká pouze žen, nebot' ovlivnila také postoj mužů k jejich tělu. Kulturní stereotypizace představ o svalnatém, a tedy i žádoucím mužském těle může někdy vyústit k užívání anabolických androgenních steroidů. Jejich nadužívání ale může po nějakém čase způsobovat neplodnost, gynekomastie, poškození myokardu, změny objemu a srážlivosti krve i poruchy metabolismu tuků (Pyšný 2002).

\section{RUB ŽIVOTA, LÍC SMRTI}

Za zcela specifický předmět výzkumů medicínské antropologie je možné označit transkulturní deskripci, analýzu a interpretaci vzájemného vztahu života a smrti. Tak jako jsou prostor a čas základními atributy hmoty, jsou fatálními atributy a limity lidské existence život a smrt. Medicínská antropologie jako věda zkoumající lékařské metody a techniky usilující o záchranu lidského života $\mathrm{v}$ různém historickém čase a geografickém prostoru je tak neoddělitelně spjatá s antropologií smrti - vědou, jež programově studuje fenomén smrti v odlišném historickém a sociokulturním kontextu. Lidé od nepaměti sváděli prostřednictvím medicíny boj o záchranu lidských životů, současně ale vždy a všude byli nuceni reagovat na příchod smrti. $Z$ antropologické perspektivy existuje jen málo tak nadčasových dichotomií jako je život a smrt. Francouzský strukturální antropolog Claude Lévi-Strauss formuloval hypotézu, že myšlení v binárních kontrastech lidem umožňuje konceptualizovat svět a vnášet logiku do světa, který je obklopuje. Vyšel přitom z předpokladu, že prvek systému nemá sám o sobě žádný smysl, ale nabývá jej tím, že vystupuje v opozici ve vztahu k jiným prvkům: „Jednotlivé členy nemají nikdy význam samy o sobě, jejich význam je opoziční a je $\mathrm{z}$ jedné strany závislý na historii a kulturním kontextu 
a $\mathrm{z}$ druhé strany na struktuře systému, $\mathrm{v}$ němž je jim dáno figurovat.“ (Lévi-Strauss 1971, 352). Možná právě proto je medicínská antropologie osudově spjatá s antropologií smrti v intencích dichotomie „líc života, rub smrti“ (Soukup 2016). Boj s nemocemi a jejich léčení představují $\mathrm{z}$ antropologické perspektivy základní lidskou zkušenost, která je pochopitelná pouze v konkrétním historickém a sociokulturním kontextu. ${ }^{6}$ Jedná se o specifický typ biokulturní adaptace, která variuje v čase a prostoru. Snaha lidí odvrátit negativní důsledky zranění a nemocí představuje kulturní univerzálii, která se promítla do širokého spektra různých lékařských systémů, které zahrnují specifické, kulturně podmíněné kognitivní a behaviorální komponenty. Součástí lékařských systémů jsou teorie etiologie, jež se snaží vysvětlit příčinu nemocí, taxonomie zranění a chorob. Ty z nativní perspektivy vnášejí do nemocí ohrožujících lidské zdraví klasifikační řád, léčebné metody a techniky umožňující odvrátit destruktivní důsledky epidemií, nemocí a zranění snižujících kvalitu lidského života. Lékařské systémy, které lidstvo $\mathrm{v}$ průběhu své existence vytvořilo, nespojuje žádné jednotné paradigma. Konkrétní biomedicínské systémy je proto nutné studovat v konkrétním geografickém prostoru a kulturním kontextu, který ovlivňoval diagnostické, léčebné a terapeutické postupy, které jsou součástí širšího institucionálního a sociokulturního systému. Již v jednoduchých preliterárních společnostech došlo v rámci lékařských systémů $\mathrm{k}$ diferenciaci dvou základních statusů a rolí, jež jsou s bojem o lidské zdraví dialekticky spjaty a které dnes označujeme kategoriemi „lékař“ a „pacient“. Nedílnou součástí vztahu lékaře a pacienta jsou na jedené straně systémy lékařských znalostí a dovedností, na straně druhé instituce, které péči o lidské zdraví zajištují. V jednoduchých domorodých společnostech byla etnomedicína často spojena s širšími symbolickými systémy, jako jsou magie a náboženství. Léčiteli zde byli např́klad šamani, kteří ke stanovení diagnózy využívali komunikaci s duchovním světem prostřednictvím transu a dalších spirituálních praktik (Singer - Baer 2011; Singer - Erickson 2015; Wiley - Allen 2016).

V komplexních společnostech existují velmi sofistikované biolékařské systémy, které jsou charakteristické vysokou úrovní specializace, hierarchie a prestiže, jež ovlivňují vzájemný vztah mezi jednotlivými lékařskými profesemi. Z perspektivy medicínské antropologie je možné klasifikovat bio-

6 Medicínští antropologové, kteří studují nemoci, zdravotní problémy, lékařské systémy a způsoby léčení nemocí a zdravotních potíží u různých etnik a národů, kladou důraz na holistický, komparativní a kontextuální př́stup. Upozorňují na skutečnost, že pod vlivem demografických, technologických, ekonomických a ekologických faktorů výskyt, diagnostika, klasifikace a léčba nemocí u různých společností variují v čase a prostoru. Např́ílad epidemické choroby jako jsou cholera nebo dýmějový mor souvisí s hustotou obyvatelstva, zemědělstvím a urbanizací. Na šiřrení malárie zase měly vliv takové faktory, jako jsou kácení lesů, růst počtu obyvatelstva a závislosti na zemědělství. Na kvalitu lidského zdraví mají v průmyslové civilizaci vliv takové stresory jako jsou hluk, znečištěné životní prostředí, špatné potravní návyky, zneužívání psychotropních látek, neosobní pracovní organizace a sociální izolace. lékařské systémy na tři různé úrovně a typy profesí. První typ zahrnuje široké spektrum konvenčních a vědecky uznávaných lékařských profesí legitimovaných a institucionalizovaných západní společností. Druhý typ biolékařských systémů zastupují lékařské profese označované jako „alternativní medicína“, jejíž součástí je v moderní společnosti již více či méně akceptovaná homeopatie, akupunktura nebo chiropraxe. Třetí typ biolékařské medicíny reprezentují léčitelé praktikující tradiční domorodou medicínu v zemích „třetího světa“. Alternativní a tradiční domorodá medicína, stojící do značné míry v opozici k západní biomedicíně, klade důraz na osobní přistup $\mathrm{k}$ léčbě pacienta a akcentuje vztah léčitel - pacient komunita. Na rozdíl od exaktně koncipované moderní biomedicíny, která má tendenci oddělovat biologické, psychologické a sociokulturní př́činy nemocí, tradiční etnomedicína neakcentuje protiklad fyzického těla a lidské mysli. Proto je často úspěšná při léčbě zdravotních problémů, které západní medicína označuje jako psychosomatické (Stepp - Wyndam Zarger 2002; Olver - Robotin 2012).

Profesní postavení lékaře stojí v přímém protikladu ke kategorii pacient, jehož status je založen na onemocnění nebo zranění. Role vyplývající ze statusu pacienta vyžaduje respektovat a důsledně plnit pokyny lékaře, postupně snižovat závislost na lékařské péči a uzdravit se. Bohužel ale na pacienta, stejně jako na lékaře, čeká dříve nebo později také fatální jistota, jíž je umírání a smrt. Proto je důležité rozšírit tradiční témata medicínské antropologie, která primárně souvisí s péčí o kvalitu života a péčí o lidské zdraví, o problematiku související s výzkumem takových dimenzí života jako je umírání a smrt. Antropologie života, jíž nesporně medicínská antropologie je, tak představuje komplementární vědní disciplínu k antropologii smrti. Součástí lidského života je totiž nejen život, ale také nemoc, umírání a smrt, s níž se každý člověk jako příslušník určité kultury musí smírit. Proto existují pohřební rituály a v celé řadě lidských společností se $\mathrm{v}$ průběhu dějin zrodila také kulturně konstruovaná víra v posmrtný život. Umírání a smrt je součástí lidského života. Medicínskou antropologii proto nelze redukovat na antropologicky koncipovaný výzkum diagnózy chorob, léčby nemocí a péče o lidské zdraví v holistické a transkulturní perspektivě. Předmětem medicínské antropologie by měl být i pohled do zrcadla odrážejícího temné stránky lidského osudu. Antropologická deskripce, analýza a interpretace smrti jako součásti života totiž umožňuje pochopit limity lidské existence a klást otázky na téma „kdo jsme, odkud jsme a kam jdeme“ (Brown - Closser 2016; Joralemon 2017).

Život a smrt představují dichotomické existenciální párové kategorie označující křehkou pomíjivost lidského osudu, který je fatálně biologicky limitován.7 Zrození člověka z hlediska existenciální filozofie německého filozofa Martina Heideggera představuje stav „vrženosti“ (Geworfenheit) do světa.

7 Smrt představuje multidimenzionální fenomén a proto je důležité při jejím výzkumu využít interdisciplinární perspektivu. Smrt je možné analyzovat jako biologickou nutnost, demografickou konstantu, sociální událost, biosociální faktor nebo kulturní konstrukci. 


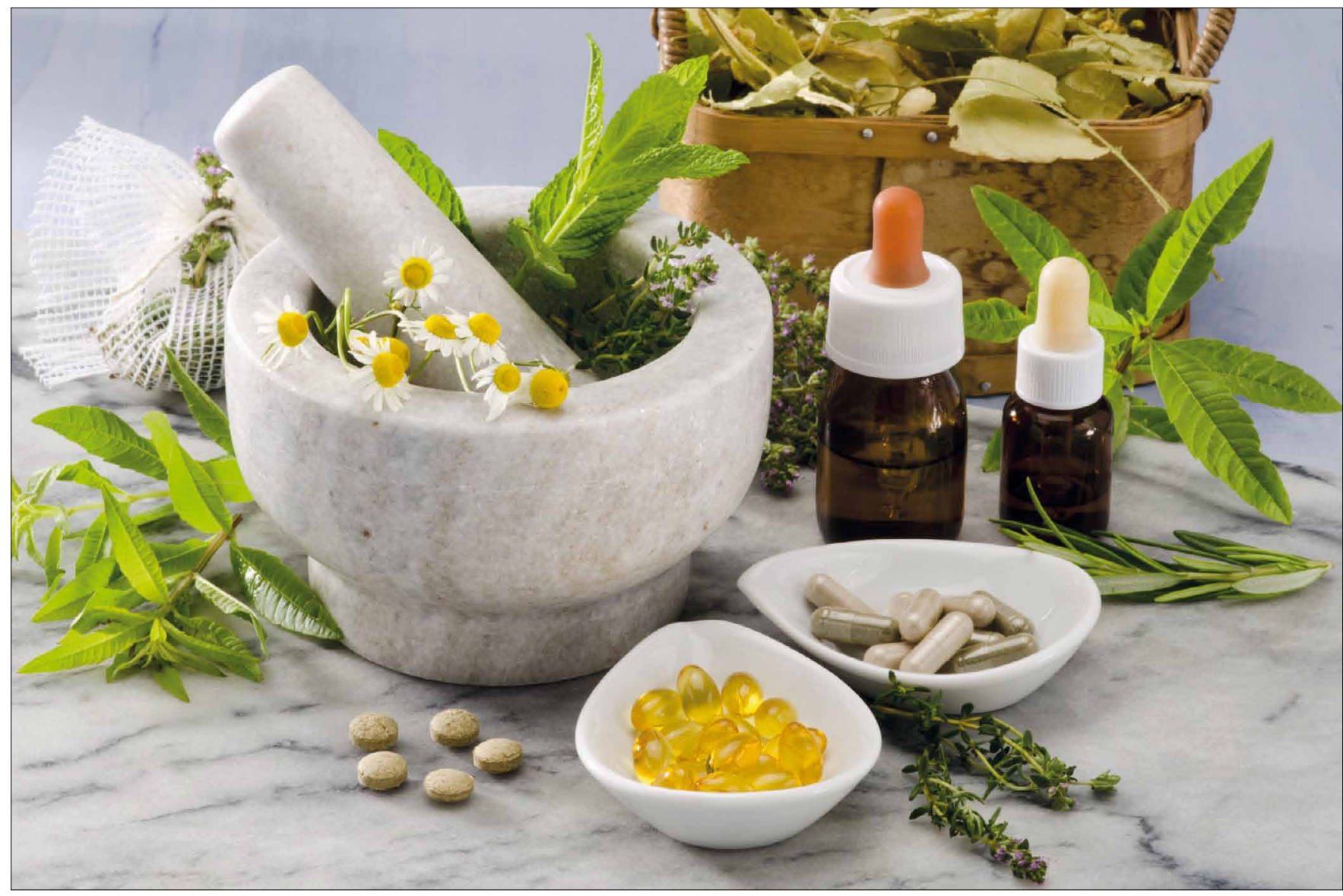

Druhý typ biomedicínských systémů reprezentují lékařské profese označované jako „alternativní medicína“. ๑ SmartGuy.

Kategorie vrženosti odráží existenciální situaci, v níž se člověk po svém narození ocitl. Nezávisle na svém přání se narodil v jím nevybrané historické epoše a konkrétním jazykovém prostředí, společnosti a kultuře, v níž je jako činný reálný subjekt nucen vstoupit do aktivního životního vztahu. Na své pouti životem má ale každý jednotlivec možnost svobodné volby. Může tak naplnit svojí existenci, která mu byla „dána“ aktem zrození, konkrétní autentickou nebo neautentickou životní esencí. Průběh života každého člověka je z této perspektivy př́během o nekonečných možnostech volby a jediné jistotě, jíž je smrt. Ta ovšem není pouze závěrečnou tečkou za lidským životem, ale také existenciální výzvou a úhlem pohledu, který může přispět k tomu, že člověk prožije autentický život (Heidegger 1927).

Zamyslíme-li se nad svojí každodenností skrze prizma skutečnosti, že naše existence je „bytím pro smrt“, dimenze úzkosti vyplývající $\mathrm{z}$ vědomí naší vlastní konečnosti nám umožní nepromarnit svůj život a prožít jej plnohodnotně. Vědomí omezenosti vlastního bytí tak může fungovat jako princip transcendence, jehož prostřednictvím člověk překračuje kruh danosti a vstupuje jako činný subjekt do autentického světa skutečných snů, záměrů a přání (Scherer 2005). Z hlediska medicínské antropologie ale postoj ke smrti stejně jako strach $\mathrm{z}$ osamělosti může fungovat $\mathrm{v}$ různém kulturním kontextu jako determinanta ovlivňující lidské zdraví a kvalitu života. Smrt v mezikulturní a historické perspektivě totiž nelze redukovat pouze na biologickou danost. Jedná se totiž také o biosociální faktor a specifickou kulturní konstrukci, která nabývá různého smyslu v kontextu konkrétní kultury. $\mathrm{Na}$ jedné straně je nám smrt dána jako biologický limit a osudová jistota vyplývající z faktu, že život je „bytím ke smrti“. Na straně druhé je na úmrtí možné pohlížet jako na kulturně generovaný „sémiotický text“ - symbolickou zprávu odkazující na znakovou a významovou dimenzi smrti. Sociologové při vymezování specifiky biosociálních faktorů jako jsou věk, pohlaví nebo etnická př́ílušnost mluví o fenoménu „askripce" neboli skutečnosti, že konkrétním lidem jsou tyto činitele „kulturně“ připsány nezávisle na jejich usilování a přání. Například každému člověku „je dáno“ být příslušníkem určitého pohlaví, jemuž se v průběhu stárnutí pozvolna a objektivně navršuje věk a na jehož konci stojí biologická smrt. Biosociální faktory neboli „prríroda v člověku“, jsou svojí podstatou sociálně neutrální a jako znaková kulturní konstrukce začnou fungovat až za určitých specifických podmínek. Za mechanismy, které z původně sociálně neutrálních faktorů vytvoří kulturní konstrukci, patří „Zvýznamněni“ a „sociokulturní kontext“. V průběhu zvýznamnění neboli „přiřazení významu“ se biosociální faktory stanou znakem - začnou zastupo- 


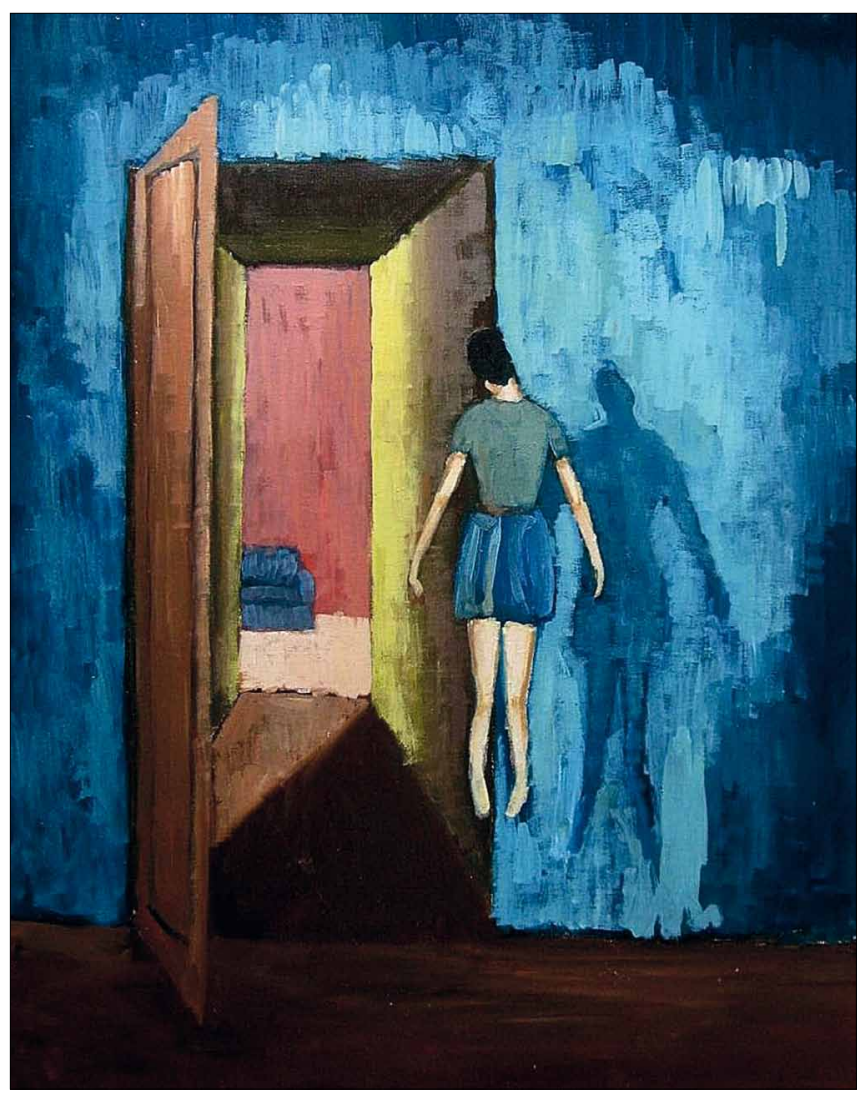

„Liminalita“ je stav pomezí a přechodu, pro který je charakteristická dvojznačnost, neurčitost, nerovnováha, zmatek a další symptomy hraniční existence oscilující mezi tím, co bylo v minulosti s tím, co bude v budoucnosti. (c) K.D. Farris.

vat něco jiného nežli biologickou danost a stanou se nositelem kulturních významů. Např́iklad stáří může být v jedné kultuře vnímáno jak jako symbol moudrosti a pozitivních životních zkušeností a v jiné kultuře naopak jako zpráva o přebytečnosti, obtížnosti a nutnosti péče o staré lidi. Podobně je tomu se smrtí, která může být v jedné kultuře chápaná jako definitivní konec lidské existence a $\mathrm{v}$ jiné jako počátek nového života. V procesu zvýznamnění hraje zásadní roli kulturní kontext, který utváří sociokulturní hodnoty, normy a ideje, jež jsou biosociálním činitelům v různých kulturách přičítány. Při studiu smrti jako biosociálního faktoru je proto nezbytné vždy analyzovat, jakou symbolickou hodnotu lidé v konkrétním historickém nebo kulturním kontextu umírání a smrti člověka přikládali (Ariès 2000; Scherer 2005; Barloewen 1996; Mühlpachr 2009; Soukup 2016).

Archeologické nálezy hrobů $\mathrm{z}$ období mladého paleolitu svědčí o tom, že již v pravěku lidé reagovali na smrt prostřednictvím pohřebních obřadů. Stopy dávných pohřebních obřadů svědčí nejen o existenci určitého náboženského povědomí, ale také o sdílených projevech altruistického cítění a symbolického sepětí světa živých a mrtvých (Svoboda 2014; Soukup 2015). O tom, jaký význam pravěcí lidé smrti přikládali a jakou konkrétní podobu měly jejich pohřební rituály, ale dnes můžeme pouze spekulovat. Podstatně více toho ovšem víme o vztahu člověka ke smrti v kontextu pohřebních rituálů z písemných záznamů a výtvarných děl, které se dochovaly $\mathrm{z}$ doby starověku, středověku a novověku. Klíčem k pochopení fenoménu smrti jako v čase a prostoru variující kulturní konstrukce, jsou náboženské systémy, v jejichž rámci lidé svůj vztah k životu a smrti řešili. Důležitou roli z tohoto hlediska sehrály v dějinách lidstva zejména náboženské systémy spjaté s buddhismem, hinduismem, judaismem, křstanstvím a islámem. Významným kulturním ohniskem těchto náboženství byly pohřební rituály, které dokonce často tvořily ideové a normativní jádro těchto společností. Provedeme-li jejich analýzu a komparaci z perspektivy medicínské antropologie, uvědomíme si, že smrt nepředstavuje pouze biologickou danost, ale také velmi proměnlivý kulturní konstrukt (Barloewen 1996; Winston 2005, 234-238).

Vědomí toho, že smrti se není možné vyhnout a odchod ze života je fatální konstantou lidského bytí, vyústilo v různých světových kulturách ve snahu umírajících i pozůstalých rituálně se smírit $s$ faktem lidské smrtelnosti. Smrt tak bylo možné vnímat jako jinou formu bytí a alternativní dimenzi lidským tělem limitované existence. Rituály spjaté s fenoménem smrti navíc byly symbolickým nástrojem „vyhoštěni“ mrtvých ze světa živých a prostředkem ochrany lidí před negativním vlivem entropie vystupující v podobě chátrání a destrukce živých organismů. Již v dávných dobách ale byla zřejmě smrt také vnímána jako logická součást cyklického plynutí času analogickému s rytmem př́rody, ve kterém se pravidelně střídají vegetativní cykly zrození, růstu, vrcholu, stáří a smrti. Skutečnost, že ve světě přírody po zimní fázi „smrti“ vegetace dochází na jaře $\mathrm{k}$ jejímu pravidelnému „znovuzrozeni“, možná inspirovala naše dávné předky $\mathrm{k}$ víře $\mathrm{v}$ nesmrtelnost duše a představě, že cyklicky dochází k jejím návratu. Smrt byla $\mathrm{v}$ tradičních společnostech praktikujících animismus často také chápána jako rozchod životního principu (duše) s jejím materiálním nositelem (lidským tělem). Dávná víra lidí, že umírání a smrt je pouhý přechod do jiného světa, kde mrtvý dál žije v pozměněné podobě, se tak promítla do pohřebních zvyků a obřadů (Barloewen 1996; Sígl 2006).

$\mathrm{Z}$ perspektivy medicínské antropologie je možné smrt, stejně jako narození nebo vstup do manželství, označit za významný a konstitutivní moment, kolem něhož se koncentrují přechodové rituály (rites de passage). ${ }^{8}$ Přechodové rituály reagují na skutečnost, že se v lidském životě v průběhu ontogeneze střídají období klidu s dobou rychlých, výrazných a mnohdy nezvratných změn. Jedná se především o události spjaté se

8 Pojem přechodových rituálů uvedl do antropologické literatury v roce 1909 Arnold van Gennep v knize Přechodové rituály. Formuloval zde vlivnou teorii, podle níž ve všech kulturách probíhají důležité změny sociálního postavení člověka ve společnosti prostř̌ednictvím rituálů, které $\mathrm{v}$ sobě skrývají univerzálně platnou strukturu. Tu tvoří trojfázové schéma přechodového rituálu, které zahrnuje fáze (1) odloučení, (2) pomezí a opětovného (3) začlenění jedince do nového statusu. Gennepovy úvahy na téma pomezí ve druhé polovině 20. století rozpracoval zejména Victor Turner v knize Průběh rituálu (1969). 
změnou statusu člověka $\mathrm{v}$ sociální struktuře, která je často doprovázena společenskými rituály ovlivňujícími život jednotlivce. $V$ první fázi těchto rituálů je člověk symbolicky nebo fakticky odloučen od statusu nebo situace, $\mathrm{v}$ níž se nacházel v minulosti. Po tomto oddělení prochází druhou fází, pro níž je charakteristický stav „liminality“. Jedná se o stav pomezí a přechodu, pro který je charakteristická dvojznačnost, neurčitost, nerovnováha, zmatek a další symptomy hraniční existence oscilující mezi tím, co bylo v minulosti s tím, co bude $\mathrm{v}$ budoucnosti. Třetí a závěrečná fáze rituálů přechodu často představuje zrcadlově obrácený odraz fáze první, nebot' se jedná o (znovu)přijetí. Jedinec, který byl na počátku odloučen, je totiž v tomto stádiu rituálu, prostřednictvím nově získaného statusu, opětovně začleněn do společnosti nebo širšího univerza sdíleného príislušníky dané kultury.

Aplikujeme-li teorii přechodových rituálů na analýzu umírání a smrti, pak můžeme ztotožnit fázi „odloučení s dobou umírání a následnou smrtí člověka, která oddělila zemřelého od jeho předešlého sociálního statusu. Zde je nutné podotknout, že každá lidská společnost se s př́íchodem smrti a faktem odchodu člověka ze světa živých vyrovnává normativně stanoveným způsobem. Fázi „pomezi“ (liminality) lze ztotožnit $\mathrm{s}$ obdobím, $\mathrm{v}$ němž probíhají ústř̌ední rituály spjaté s loučením se zesnulým. Jejich součástí je obvykle pohřební průvod a s ním spjaté obřady a vzorce chování. V tomto stádiu je ritualizovaný vztah k zesnulému konstruován ze strany pozůstalých v kulturních kategoriích zdůrazňujících přechod z minulosti do budoucnosti. Závěrečnou fázi neboli „začlenění 'lze ztotožnit $s$ pohřbem a aktivitami souvisícími s uctíváním předků a zesnulých. Prostřednictvím těchto obřadů se zesnulý v nově získaném statusu opět stává součástí ideových systémů dané společnosti a nachází tak i nové místo v univerzu, které tvoří nedílný kontextuální rámec každé kultury (Gennep 1997).

Mezikulturní výzkumy medicínských antropologů mohou významným způsobem přispět $\mathrm{k}$ poznání toho, jak $\mathrm{v}$ různých kulturách léčitelé a jejich pacienti přistupují k lidskému zdraví, nemocí, umírání a smrti. Problematika zdraví a nemocí postihujících lidské tělo ale představuje velkou výzvu také pro klasickou fyzickou antropologii a paleoantropologii, které studují proměny lidského organismu v evoluční perspektivě. $\mathrm{V}$ průběhu antropogeneze lze totiž vysledovat existenci vztahu mezi proměnami životního prostředí, potravní strategií našich evolučních předkủ, lidským zdravím a nemocí. „Obecná neschopnost naší společnosti uvažovat o lidské evoluci je hlavním důvodem naší neschopnosti účinně předcházet nemocem, jimž se předcházet dá. Naše těla mají príběh - evoluční př́běh -, od kterého se toho hodně odvíjí. Jednak evoluce vysvětluje, proč jsou naše těla taková, jaká jsou, a nabízí tak vodítka, jak předejít onemocněním. Proč máme takový sklon $\mathrm{k}$ tloustnutí? Proč se někdy jídlem dokážeme doslova udávit? Proč se klenba našich nohou někdy bortí? Proč máme záda, která bolí? Evoluční př́iběh našeho těla bychom měli brát v úvahu i proto, že nám pomůže pochopit, na co naše těla jsou a na co nejsou adaptovaná." (Lieberman 2016, 11)

\section{ZDRAVÍ A NEMOC V EVOLUČNÍ PERSPEKTIVĚ}

Úsvit lidstva je spjatý se vznikem dvojnohých afrických primátů, kterým říkáme homininé. Tímto pojmem antropologové označují současné lidi a všechny jejich bipední pravěké předky. Ti se před 7 až 5 miliony let oddělili od od afrických lidoopů a zahájili tak dlouhou evoluční odyseu směřující $\mathrm{k}$ současnému anatomicky modernímu člověku. Ranní archaičtí homininé (Sahelanthropus tchadensis, Ardipithecus ramidus, Orrorin tuganensis) svým vzhledem ještě připomínali lidoopy, ale lišili se od nich chủzí po dvou končetinách. Transformace lidoopů do podoby vzpř́mených dvojnožců představuje klíčový zvrat $\mathrm{v}$ evoluci lidského těla, nebot zbavila horní končetiny jejich původní lokomotorické funkce a vytvořila předpoklady pro vznik lidských rukou. Chůze po dvou končetinách navíc byla energeticky výhodná a umožňovala efektivně transportovat $\mathrm{v}$ krajině rozptýlenou rostlinou potravu. Vzpř́mený postoj byl také užitečný při sběru plodů, které rostou na větvích stromů a keřủ. Důležité také je, že umožňoval vizuální kontrolu teritoria a tím i ochranu před nečekaným útokem nebezpečných predátorů.

Vzpř́mená chůze, která znamenala doslova revoluci ve vývoji lidského těla, ale přinesla se sebou také řadu zdravotních problémů, s nimiž se dnes lidé potýkají. Vedlejším produktem přestavby lidské kostry do vzpř́mené polohy jsou např́ílad bolesti zad, ztuhlý krk, potíže s koleny a občasné problémy se zvrtnutými kotníky. Ještě větší daň za bipedii zaplatily ženy, kterým v době těhotenství komplikuje život narůstající váha, která postupně posouvá těžǐště těla před kyčle a nohy, čímž vzpř́mený postoj ztrácí na stabilitě. Snaha budoucích matek eliminovat tyto negativní faktory, vede k tomu, že ve zvýšené míre zapojují do pohybu zádové svaly nebo mají tendenci se zaklánět, což ale má negativní vliv na bederní obratle, které se „rozjíždějí. Vysokou cenu za bipedii ženy také zaplatily tím, že vzpř́ímená chůze vyžaduje užší boky, což v průběhu evoluce vedlo $k$ přestavbě pánve a zúžení porodního kanálu. Stavba pánve totiž musí umožňovat jak chůzi po dvou končetinách, tak porod dítěte $s$ velkým mozkem a širokými rameny. Otvor ženské pánve je ale u anatomicky moderního člověka tak stísněný, že se plod při své cestě porodním kanálem musí pootáčet. Někdy dokonce v průběhu porodu dochází ke zmáčknutí hlavičky novorozence, aby se lebka o několik milimetrů stlačila a dítě se tak mohlo dostat na svět. Ve srovnání s člověkem rodí většina primátů snadněji. Např́ílad šimpanzí mládě do prostoru pánve vstupuje i vystupuje relativně rychle, bez otáčení a rodí se $s$ tvárí vzhưru, takže ho matka může sama vytáhnout ven. Bipedie způsobila, že se porod lidských dětí stal komplikovaným, nebot velikost hlav novorozenců byla limitujícím faktorem a nezanedbatelným rizikem pro život dítěte i matky. Řešením, které „zvýhodnil“ přírodní výběr, byly porody probíhající v době, kdy byly hlava a mozek dítěte relativně malé a poměrně tvárné. Lidé tak ve srovnání s jinými primáty začali rodit své děti předčasně, což se již v pravěku promítlo do zvýšené bezmocnosti novorozenců, kteří potřebovali větši mateřskou péči. Mezi další nevýhody přechodu z kvadrupedie na bipedii u archaických homininů patřila 
ztráta rychlosti (ve srovnání s čtyřnohými lidoopy) a snížení schopnosti šplhání v korunách stromů (ve srovnání s šimpanzi). Vznik bipedie u prvních homininů je klasickou ukázkou „evolučního obchodu“, který necíleně provádí prrírodní výběr a současně funguje na principu „něco za něco“. Vzpř́ímená postava a uvolnění předních končetin na jedné straně poskytly předkům člověka adaptivní výhodu, kterou v následujících fázích evoluce úspěšně využili k přetváření přírody prostředky kultury. Na straně druhé ještě dnes anatomicky moderní lidé platí za evoluční „dar bipedie“ zdravotními problémy (Susman - Stern 1983; Harari 2013; Soukup 2015; Lieberman 2016).

Bipedie ale byla jen prvním krokem $\mathrm{k}$ dalším proměnám těla našich prredků. Nová kapitola v evoluci lidstva je spjatá s př́íslušníky rodu Australopithecus, jehož četné druhy obývaly před 4,2-1,4 milionu let území východní, střední a jižní Afriky. Evolučním ohniskem byli před 4,1 až 3 miliony let východoafričtí reprezentanti druhu Australopithecus afarensis. Jejich potravní základna vedle ovoce, poživatelných listů a semen zřejmě zahrnovala výživné „nouzové potraviny“ skryté pod zemí v podobě kořenů, hlíz nebo cibulí. Doplňkovým zdrojem stravy mohl být také hmyz a drobní obratlovci. Pravěcí homininé tak získali nový „evoluční dar“, s jehož důsledky se dnes potýká i anatomicky moderní člověk. Na evoluční scénu totiž vstoupil všeho schopný „všežravec“. I za tento dar, který byl „digitální řekou DNA“ předáván z generace na generaci, dnes anatomicky moderní lidé platí svou daň v podobě ničím nelimitované všežravosti a následné obezity (Susman Stern 1983; Henke - Tattersall 2007; Lockwood 2008).

Adaptační potenciál, spjatý s bipedii a všežravostí, začali úspěšně uplatňovat první zástupci rodu Homo, kteří se od australopitéků odštěpili před 2,8 až 2,5 milionu let. Základ jejich jídelníčku sice tvořila, stejně jako u australopitéků, převážně rostlinná strava, tu ale dokázali doplňovat masem zbylým z kořisti masožravých dravců a $z$ těl přirozeně uhynulých zvířat. Jinými slovy raní př́ílušníci rodu Homo svoji všežravost v oblasti živočišných proteinů uspokojovali prostřednictví mrchožroutství. Významnou roli v této nové potravní strategii zřejmě již sehrávaly jednoduché kamenné nástroje (oldowanská industrie), které ovšem nesloužily k lovu, ale k tomu, aby naši mrchožroutští předci odřezali zbytky masa $\mathrm{z}$ kostí již mrtvého zvířete nebo jimi rozdrtili jejich kosti, aby získali cenný živočišný morek. Tato potravní strategie se úspěšně promítla do dalšího „evolučního daru“, který zásadním způsobem ovlivnil nejen genezi člověka a kultury, ale také osud současných lidí. Tímto darem byl „rozpínající se mozek“. Asi před 2 miliony let došlo u př́slušníků druhu Homo habilis $\mathrm{k}$ růstu objemu mozku. Nárůst šedé mozkové kůry, zejména rozvoj neokortexu umožnil prríslušníkům lidského rodu ve stále větší míre a kvalitativně novým způsobem přijímat a zpracovávat informace o vnějším světě. Další růst oběmu lidského mozku, který před 1,8 až 1,4 milionu let proběhl u druhů Homo ergaster a Homo erectus, pozitivně ovlivnil vývoj materiální technologie (acheulská industrie) a umožnil stále více přetvářet př́rodu prostředky kultury. Zvětšující se mozek byl ale z hlediska jeho požadavků na prŕ́jem energie „danajský dar“.

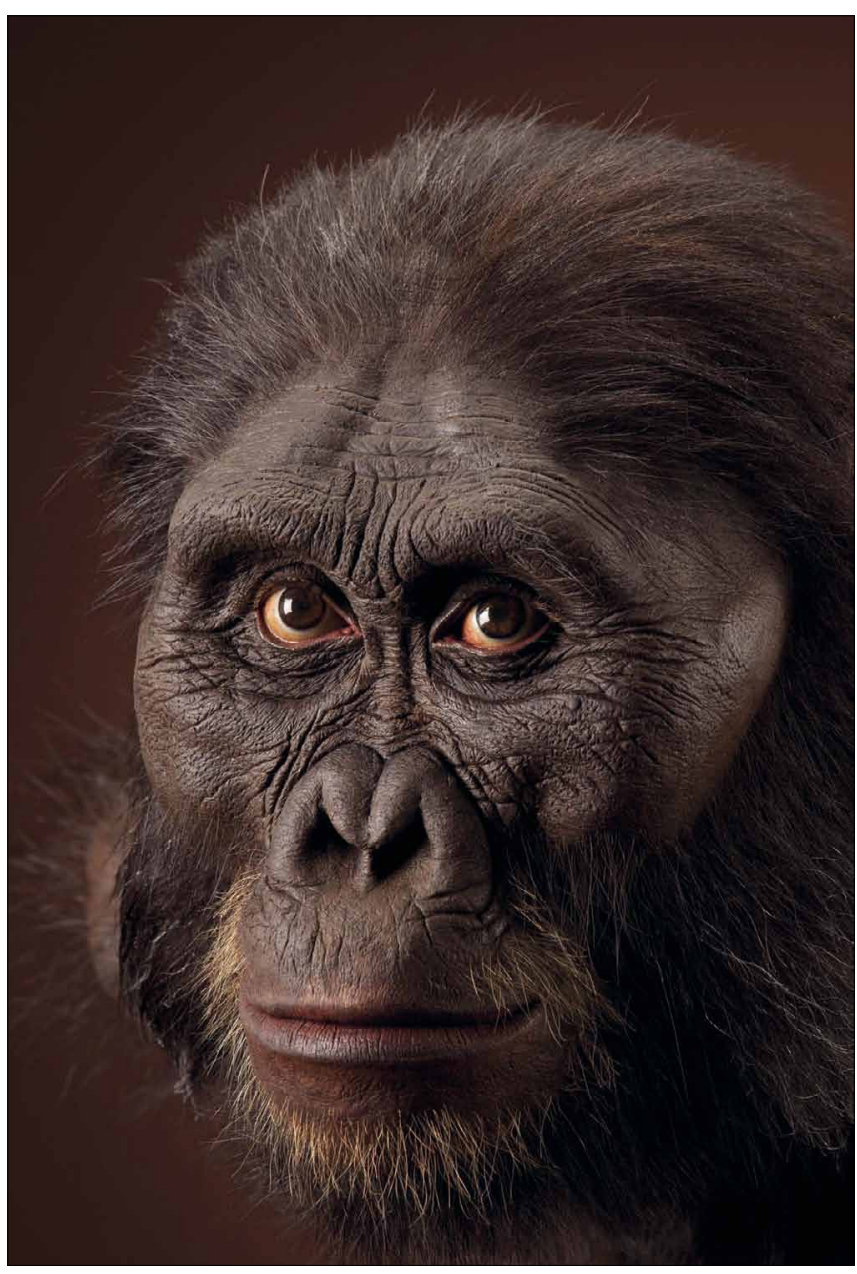

Potenciálním evolučním ohniskem směřujícím k rodu Homo mohl být druh Australopithecus afarensis. (C) John Gurche.

Bipedního „Všežravce“ na jeho evoluční pouti totiž začal doprovázet „požírač“ energie lidského těla - mozek. Řešením, které se pozitivně promítlo do efektivního fungování lidského organismu, byla narůstající konzumace masité a tepelně upravované potravy. Richard Wrangham v této souvislosti formuloval hypotézu, že $\mathrm{v}$ této fázi lidské evoluce nebylo podstatné pouze to, co lidé jedli, ale také to, jak potravu př̀ed konzumací tepelně upravili. Podle jeho názoru základní podíl na zkracování délky střev a růstu objemu lidského mozku $\mathrm{v}$ průběhu antropogeneze měly dva základní faktory - zvyšující se konzumace masa a jeho tepelná úprava (Wrangham 2009). Bipedie, všežravost, artefakty, mozek a užívání ohně představují základní faktory ovlivňující evoluci lidského těla i jeho schopnost uchovat si zdraví a úspěšně čelit nemocem. Před 700 až 200 tisíci lety již využili archaičtí Homo sapiens, reprezentovaní druhem Homo heidelbergensis, tento adaptivní potenciál k vytvoření „podvojné ekonomiky“ založené na sběru rostlinných plodin a stále více efektivnějším lovu, který se stal zdrojem živočišných proteinů. Kolébkou lidstva byla i nadále Afrika, kde se před 200 až 140 tisíci lety objevili první anatomicky moderní lidé - druh Homo sapiens. Před 75 tisíci lety se příslušníci tohoto druhu úspěšně začali šírit „ven 


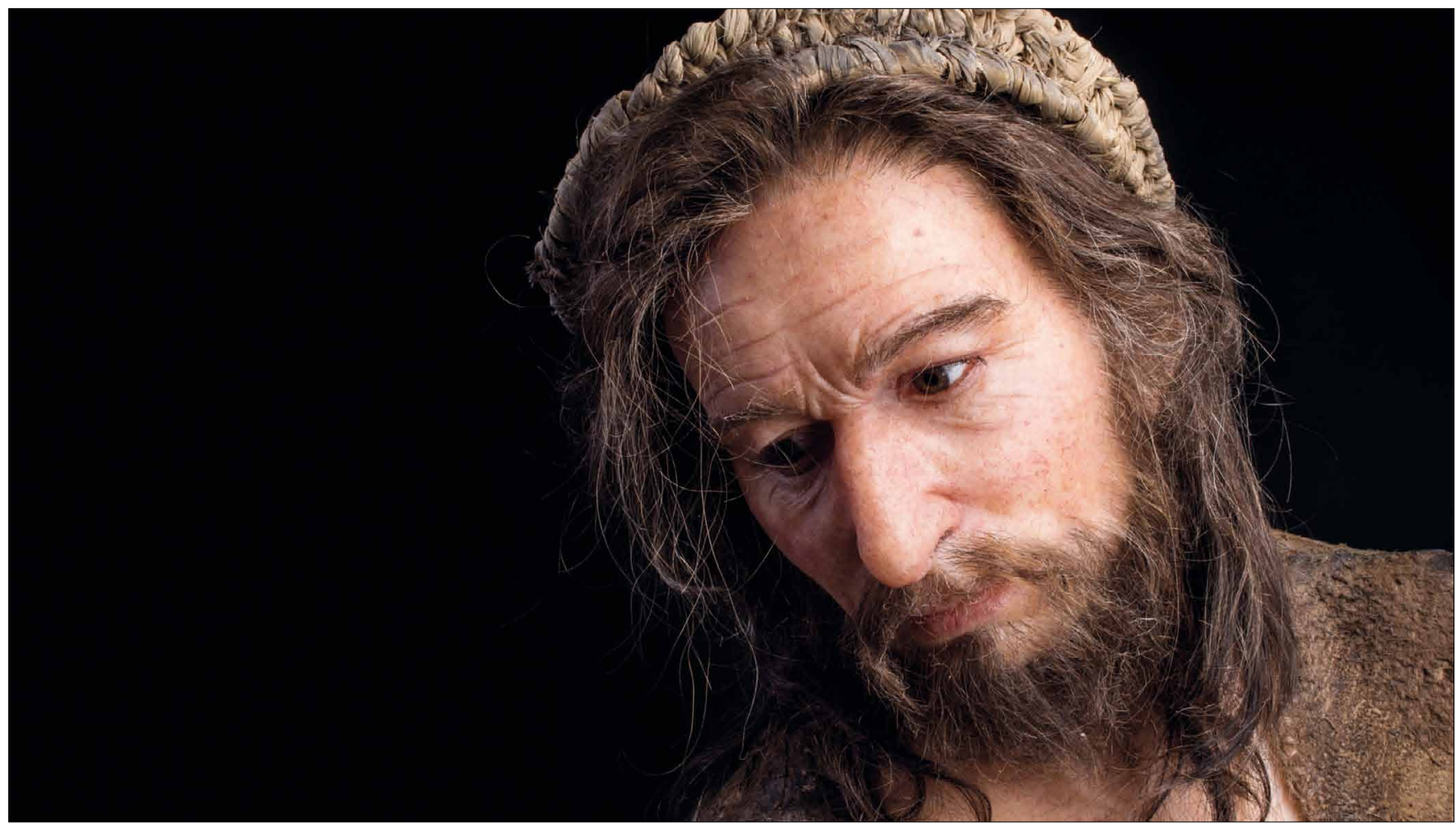

Kolébkou lidstva byla Afrika, kde se před 200 až 140 tisíci lety objevili první anatomicky moderní lidé - druh Homo sapiens. (C) Matteo De Stefano.

z Afriky“, aby v relativně krátké době osídlili celý svět a jako úspěšní lovci a sběrači stanuli na vrcholu potravního řetězce. Pro pochopení medicínských problémů, které ovlivňují fungování lidského těla, je nezbytné obrátit pozornost k původnímu prostředí evolučních adaptací („environment of evolutionary adaptedness") našich homininních předků. Rozhodující fáze antropogeneze jsou totiž spjaty s horkým slunečním klimatem, savanou a lesostepí východní Afriky. V té době lidé žili v malých lovecko-sběračských tlupách s poměrně složitou sociální strukturou a recipročními vzorci chování. Efektivní interakce s ostatními př́slušníky tlupy byla pro přežití stejně důležitá jako schopnost úspěšně čelit predátorům nebo zajistit dostatečné množství potravy. Právě v tomto ekologickém a sociálním prostředí vznikly specifické adaptivní problémy, jimž byli naši předkové nuceni čelit, aby přežili a předali své geny príštím generacím. Lze předpokládat, že $\mathrm{v}$ průběhu evoluce lidského rodu přirozený výběr přispěl ke vzniku takových mentálních modulů a vzorců chování, které v tomto prostředí umožnily řešit následující adaptivní problémy:

1. Moduly úniku před predátory - schopnost včas odhalit potenciální neprrátele a spustit únikové nebo obranné vzorce chování.

2. Moduly potravních preferencí - orientace na výživné zdroje potravy obsahující zvýšené množství tuku a cukru a schopnost eliminace potravy jedovaté a nepoživatelné.

3. Moduly utváření spojeneckých svazků - preference reciprocity a posilování principu prátelství, spojenectví a kolektivní spolupráce.
4. Moduly zajištující pomoc dětem a jiným příbuzným - intenzivní nereciproční altruismus ve vztahu $\mathrm{k}$ vlastním dětem a př́buzným včetně alokace zdrojů potomkům.

5. Moduly čtení mysli - schopnost odhadovat, co si jiní lidé myslí na základě empatie a sledování jejich mluvy a jednání.

6. Jazykové moduly - adaptační mechanismus umožňující přenos informací a komunikaci s ostatními lidmi.

7. Moduly výběru partnera - reprodukční strategie zajištující úspěšné předávání genů dalším generacím (Evans - Zarate 2002).

Tyto základní moduly sehrály klíčovou roli v průběhu evoluce lidstva. Díky přirozenému výběru se staly rozhodující strategií zajištující přežití v původním prostředí evolučních adaptací a dodnes přetrvávají v mentální výbavě současného člověka. Anatomicky moderní lidé totiž opustili Afriku teprve před 75 tisíci lety a období přetváření světa zemědělskými technologiemi zahájili před pouhými 11 až 8 tisíci lety. Z perspektivy medicínské antropologie je proto nezbytné si uvědomit, že moduly, které dnes užíváme $\mathrm{k}$ řešení adaptivních problémů, nevznikly $\mathrm{v}$ prostředí usedlých zemědělských nebo průmyslových společností, ale jsou produktem světa doby kamenné (Barkow - Cosmides - Tooby 1997). Psychické a fyzické adaptace, jimiž dnes lidé disponují, byly totiž plně funkční $\mathrm{v}$ původním prostředí evolučních adaptací, ale jsou již špatně použitelné nebo nepoužitelné v současném moderním světě. Pro medicínskou antropologii je toto zjištění naprosto zásadní. Umožňuje totiž pohližzet na celou řadu současných nemocí jako na „nemoci z nesouladu“. Zdrojem „evolučního nesoula- 


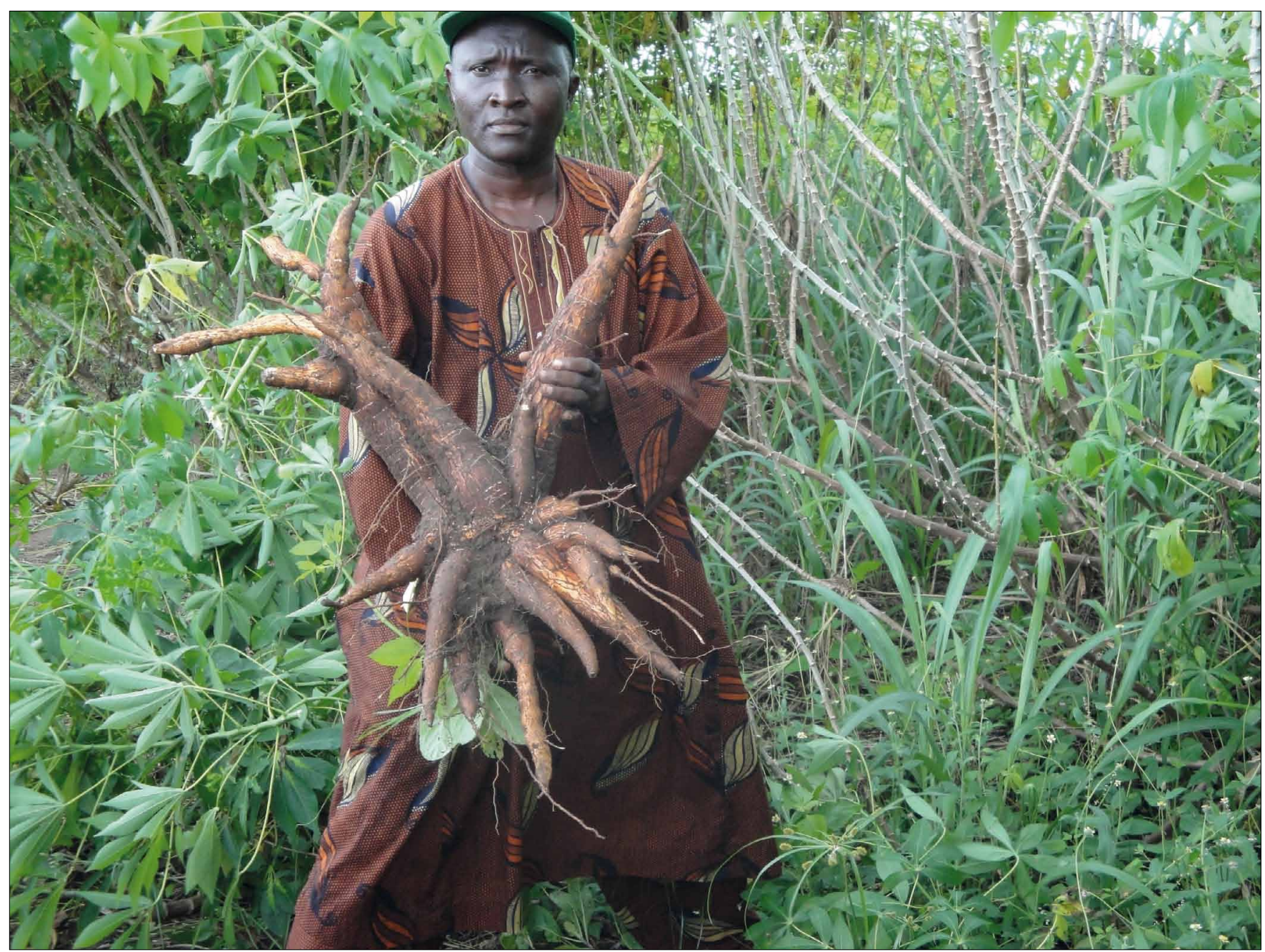

Významným mezníkem v evoluci lidstva, který způsobil růst „nemocí z nesouladu“ a ovlivnil zdraví lidí, se stal přechod od sběru a lovu k pastevectví a zemědělství. @ Joseph Nevadomsky.

du“ je na jedné straně kulturní evoluce, která prostřednictvím lidské invence a inovace přetváří svět, který nás obklopuje, na straně druhé je to migrace, $v$ jejímž průběhu lidé vstupují do nových prostř̌edí, na která ale lidská těla nejsou dostatečně adaptována. „Existuje hodně onemocnění $\mathrm{z}$ nesouladu, ale všechna jsou důsledkem změn prostředí, jež pozměňují fungování těla. Nejjednodušším způsobem, jak klasifikovat onemocnění z nesouladu, je podle změny podnětu životního prostředí. Široce řečeno, většina onemocnění nastává, když obvyklý podnět vzroste nebo naopak klesne pod úroveň, na kterou je tělo adaptované; nebo když je podnět zcela nový a tělo na něj není adaptováno vůbec.“ (Lieberman 2016, 185). Lidské zdraví v období pravěku neovlivňovaly pouze potravní, ekologické a klimatické faktory, ale také úrazy, strádání, nemoci a zranění. Archeologické a paleopatologické nálezy svědčí o tom, že naši předkové byli sužováni např́iklad artrózou nebo zlomeninami končetin. Je ale zřejmé, že př́íslušníci loveckých a sběračských společností většinou netrpěli podvýživou a disponovali poměrně pestrými zdroji potravy. Obtěžovali je sice parazitičtí červi, klíštata a různé druhy čle- novců, kteří jsou zdrojem abovirových infekcí, ale neštovice, spalničky nebo chřipka je neohrožovaly. Nízký počet členů migrujících tlup a neustálá změna tábořišt je chránily před infekčními chorobami vznikajícími demografickým růstem a kumulací odpadu a nečistot. V neposlední řadě způsob života spjatý s lovem zvířat a sběrem rostlinné potravy podporoval jejich fyzickou zdatnost. Lze předpokládat, že součástí léčení byly kromě ošetření fyzických zranění také léčebné rituály spjaté se šamanismem. Nelze také vyloučit znalost a používání léčivých rostlin.

Významným mezníkem v evoluci lidstva, který způsobil růst nemocí z nesouladu a fatálně ovlivnil zdraví lidí, se stal přechod od sběru a lovu $\mathrm{k}$ pastevectví a zemědělství. Bipední všežravec, s mozkem anatomicky moderního člověka, před 11 až 8 tisíci lety zahájil éru neolitické revoluce spjaté s kultivací a regulovaným pěstováním rostlin a domestikací zvířat. Kočovný způsob života původních sběračů a lovců byl postupně nahrazen budováním trvalých sídel, která zemědělcům a pastevcům umožňovala starat se o svá pole a stáda dobytka. Zamyslíme-li se nad genezí zemědělství z biblické perspekti- 


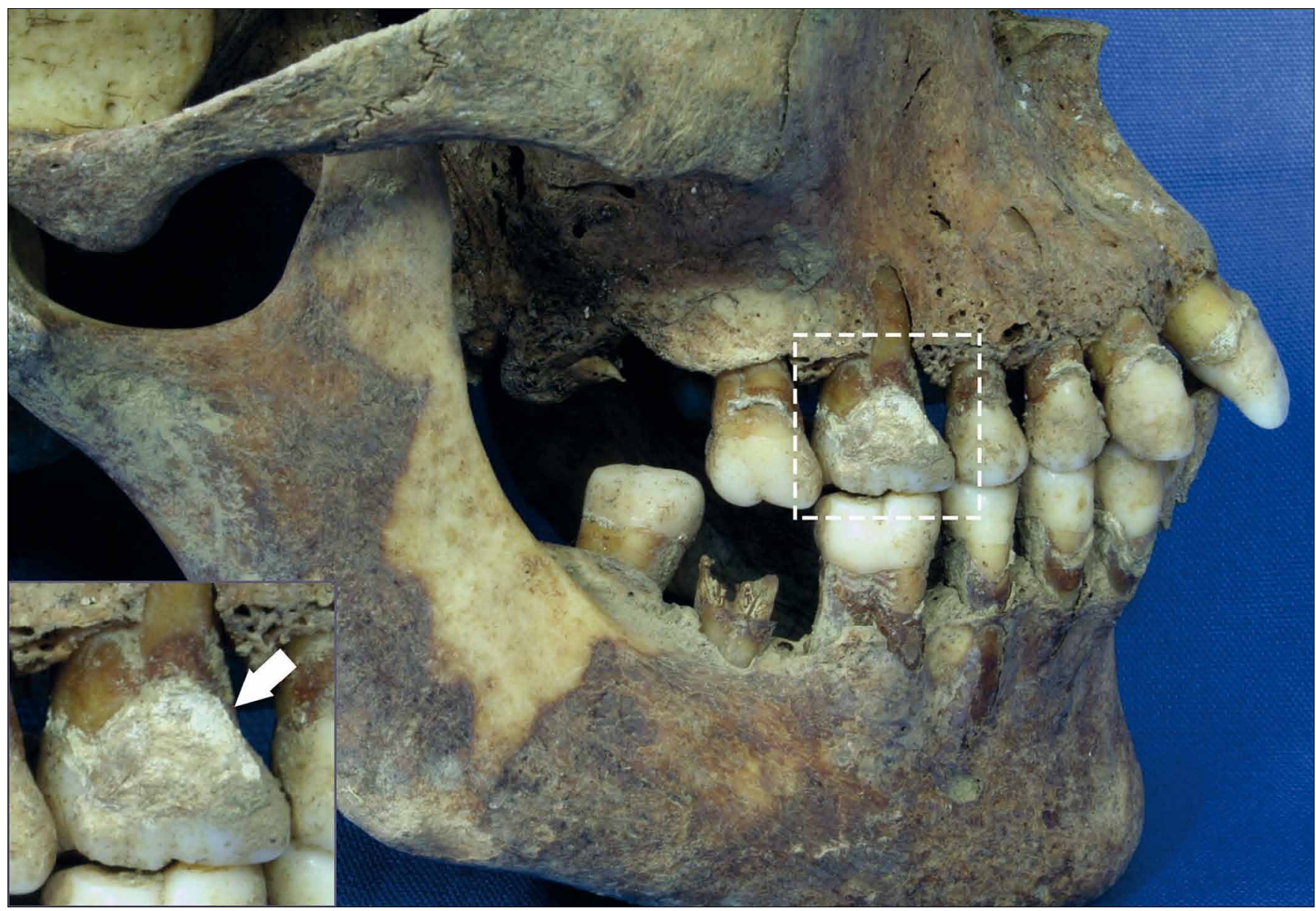

Zemědělská revoluce se sebou přinesla i závažné zdravotní problémy související se zvýšenou konzumací sacharidů (škrobu), které při konzumaci zemědělských produktů ulpívají na zubech a prritahují bakterie. @ Phys.org

vy, pak můžeme vnímat vyhoštění Adama a Evy z ráje, který oplýval hojným a snadno dostupným lahodným ovocem, $\mathrm{k}$ odsouzení lidského rodu $\mathrm{k}$ lopotnému životu zemědělců, kteří byli nuceni bojovat „, potu tváře“ o svůj „chléb vezdejší“. Pohlédneme-li na neolitickou revoluci z perspektivy medicínské antropologie, zjistíme, že kontrolovaná produkce zemědělských a živočišných potravin se promítla do způsobu života našich předků nejen v oblasti stravování, ale také v tom, jak se lidé biologicky reprodukovali, programovali své pracovní aktivity, regulovali svojí tělesnou teplotu, reagovali na infekční nemoci nebo jak mezi sebou komunikovali a kooperovali. Změny, které způsobila neolitická revoluce, měly zásadní význam pro evoluci lidského těla, šíření nemocí a snížení kvality života velké části lidské populace. $\mathrm{Na}$ evoluční scéně se totiž ve stále větší míře začaly prosazovat nové nemoci, zvýšená kazivost zubů, nutriční nedostatky a infekční epidemie. Někteří vědci, jako např́klad Jared Diamond, se proto domnívají, že přechod k zemědělství byl „největší chybou“ lidstva. Na rozdíl od pestrého jídelníčku lovců a sběračů, kteři konzumují mimořádně pestrou stravu, zemědělci redukovali svůj jídelníček na několik málo základních plodin s vysokým výnosem. To ve svých důsledcích vedlo ke ztrátě nutriční pestrosti jejich stravy a nižšímu obsahu vitamínů a minerálů, než který obsahují divoce rostoucí rostliny, jimiž se živí lovci a sběrači (Diamond 2000). Škrobovitější potraviny, které neolitičtí zemědělci konzumovali, obsahovaly méně vláknin, bílkovin, minerálů i vitamínů. „Jídelní lístek“ evropského zemědělce v období neolitu primárně tvořil chléb upečený z pšenice, ječmene nebo žita. V podobě př́lohy (nebo samostatné potravy) vystupoval hrách nebo čočka. Tuto fádní stravu doplňovaly mléčné výrobky (mléko, sýry), sezónní ovoce a př́ležitostně i maso. Jednostranná potrava ale nebyla jediným limitem ovlivňujícím lidské zdraví a evoluci lidského těla. Nebezpečná byla také orientace na pěstování několika málo nebo dokonce jenom jedné zemědělské plodiny, což fatálně zvýšilo (v případě neúrody) riziko hladomorů (Barker 2006).

Mezi další významný faktor, který negativně ovlivňoval stravu neolitiků, patři skladování zemědělských plodin, jež způsobuje pokles kalorického obsahu potravin a zvyšuje riziko jejich kontaminace škodlivými látkami nebo plísní. Zemědělská revoluce se sebou přinesla i závažné zdravotní problémy související se zvýšenou konzumací sacharidů (škrobu), které při konzumaci zemědělských produktů ulpívají na zubech a prritahují bakterie. $\mathrm{V}$ ústech se množící se bakterie při trávení cukrů vylučují kyselinu, která destruuje zubní sklovinu a způsobuje zubní kazy. Ty se již v období neolitu staly zdro- 


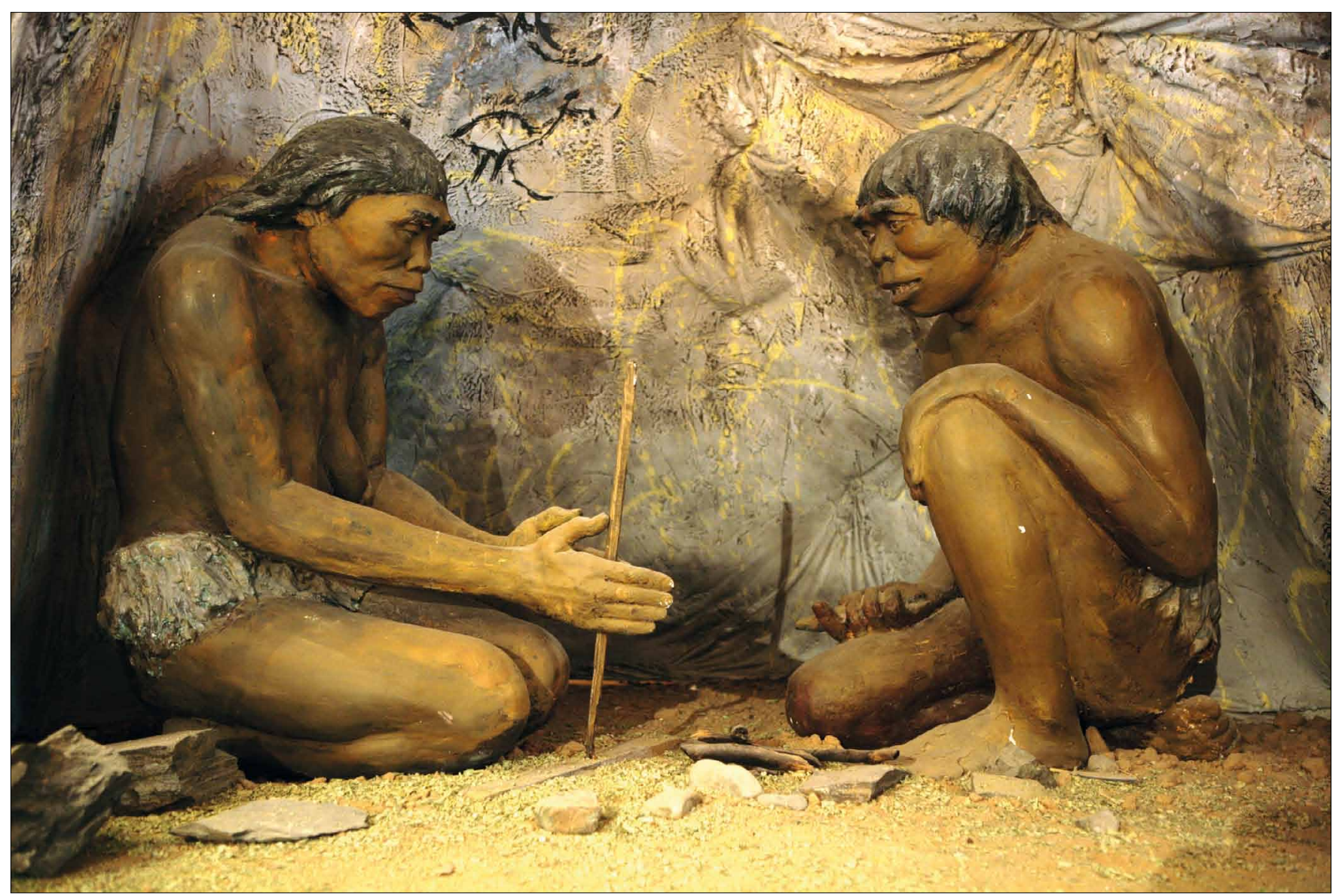

Významný zvrat $\mathrm{v}$ životě pravěkých lidí znamenalo napřed přiležitostné a poté pravidelné užívání ohně. @ Nathan McCord.

jem značných bolestí a způsobovaly fatální infekční záněty čelistí. „U lovců a sběračů se zubní kazy vyskytují vzácně, ale u prvních zemědělců jsou naprosto běžné. Na Blízkém východě vyskočilo množství jedinců s kazy ze zhruba 2 procent před nástupem zemědělství na 13 procent počátkem neolitu; v pozdějších obdobích se dále zvyšovalo..." (Lieberman 2016, 211-212)

Škrobnaté potraviny ovlivňují také tělesný metabolismus, např́klad tím, že způsobují nárůst cukru v krvi, s nímž se není lidská trávicí soustava schopna efektivně vypořádat. Př́liš rychlý prrísun nadměrného množství cukru proto může vyvolat tak závažné onemocnění jako je cukrovka. Destruktivní vliv sacharidů se sice v plném rozsahu projevil až $\mathrm{v}$ moderní, průmyslově vyráběné potravě, ale již organismus neolitických zemědělců, se s př́livem cukru do organismu pokoušel adaptivně vyrovnat zvýšením produkce inzulínu.

Dalším kontroverzním důsledkem neolitické revoluce byl růst počtu populace. Stále více potomků totiž vyžadovalo stále více potravin a zvyšovalo hustotu populace koncentrovanou ve stále více rostoucích neolitických sídlech. Vysoká koncentrace obyvatel společně s růstem obchodu ale usnadňovala šíření infekčních nemocí. Na evoluční scéně se tak s příchodem neolitu objevil fenomén epidemií, který mezi lovci a sběrači téměř neexistoval. $\mathrm{V}$ průběhu dalšího vývoje se tak metlou lidstva staly takové nemoci, jako jsou tuberkulóza, lepra, malárie, syfilis, mor, neštovice nebo chřipka. $K$ nárůstu počtu infekčních nemocí přispěla také domestikace zvířat. Příliš blízký kontakt s dobytkem má například podíl na šíření tuberkulózy, spalniček a záškrtu, zatímco chřipka se šírila od prasat a kachen. Maso navíc obsahovalo i mikroby tyfu, brucelózy nebo hemoragické horečky. Hrozbou pro lidské zdraví byly také organismy žijící s člověkem v symbióze - tasemnice a bakterie (Porter 2001).

$\mathrm{K}$ paradoxům neolitické revoluce patřila neustálá oscilace mezi jejími klady a zápory. Na jedné straně vedl vznik zemědělství ke zvýšení objemu dostupné potravy, což umožnilo růst počtu obyvatelstva, na straně druhé investování potravních přebytků do potomků prohlubovalo závislost lidí na zemědělské produkci. Na Blízkém východě lze z kosterních pozůstatků neolitiků vyčíst, jak přechod $\mathrm{k}$ novému způsobu obživy modifikoval výšku lidského těla. O úspěchu neolitické revoluce v její počáteční fázi svědčí skutečnost, že vy̌ška před 12 až 11 tisíci lety lidí stoupla o téměř 4 centimetry. Již před 8 až 7 tisíci lety se ale do výšky postavy promítl nutriční stres a šírící se nemoci, což vedlo k postupnému snižování výšky lidského těla (Simmons 2011). Podobný trend, svědčící o tom, že těla zemědělců negativně ovlivňovaly infekční choroby, dřina na polích, jednostranná skladba potravy a občas- 
né nedostatky jídla, lze zaznamenat také v Mezoamerice, kde došlo k redukci výšky lidského těla $\mathrm{v}$ průměru o 7 centimetrů nebo v neolitické Číně, kde bylo zaznamenáno snížení výšky lidského těla o 8 centimetrů (Lieberman 2016). Po počátečním úspěchu neolitické revoluce se začala prosazovat její „odvrácená tvářc, která poznamenala jak lidská těla, tak sociální vztahy založené na nerovnosti a vykořistování, které se zrodily společně se vznikem prvních starověkých států.

\section{OTEVŘENÁ PANDOŘINA SKŘÍŇKA}

Na úsvitu lidstva byli naši dávní předkové bezbranní bipední primáti, jejichž primárním zdrojem potravy byla rostlinná strava. V průběhu evoluce pravěcí lidé úspěšně rozšírili svojí potravní strategii o systematické vyhledávání a konzumaci pozůstatků hostin výkonných predátorů, jakými jsou lvi nebo tygři. Mrchožroutská orientace a př́ležitostný lov malých zvířat postupně poskytly našim předkům cenný zdroj živočišných proteinů a stimulovaly růst jejich mozků. V následujícím vývojovém období se proto objevují první komplexní sběračsko-lovecké lidské populace. Život pravěkých lidí zásadním způsobem determinovaly dva živly - voda a oheň. Voda jako př́rodní zdroj byla základní podmínkou lidské existence. Její zdroje ovlivňovaly pohyb migrujících tlup lovců a sběračů i výběr místa pro trvalejší sídla. Významný zvrat v životě pravěkých lidí znamenalo napřed př́ležitostné a poté pravidelné užívání ohně. Tepelná úprava potravy pozitivně ovlivnila růst mozku a vedla k redukci střev, chrupu a žvýkacích svalů. Ovládnutím ohně byla završená evoluční cesta od „syrového k vařenému“ a narýsována symbolická čára, která oddělila člověka od prrírody.

V době vzniku a šíření anatomicky moderního člověka, který získal hrdé označení Homo sapiens, již lidé nebyli pouhé oběti velkých šelem. Díky efektivním loveckým technologiím a „touze po masu“ lidé vyhubili četné druhy megafauny, která na řadě světadílů s jejich příchodem fatálně mizí. Kvalitativní zvrat v evoluci lidstva znamenala neolitická revoluce, v jejímž průběhu začali lidé místo lovu a sběru programově pěstovat zemědělské plodiny a domestikovat zviŕata. Tato změna potravní strategie ovlivnila jak vztah člověka $\mathrm{k}$ př́rodě, tak jeho fyzický stav a náchylnost $\mathrm{k}$ nemocem. Součástí života anatomicky moderních lidí se staly „nemoci z nesouladu“, vyvolané maladaptací na nové životní prostředí. Vliv potravy na lidské tělo a životní způsob př́slušníků druhu Homo sapiens, ale neolitickou revolucí zdaleka neskončil. V období průmyslové revoluce, která představovala další klíčové období vývoje lidstva, strojová výroba začala radikálně proměňovat potravní strategie lidstva. Charakteristickým rysem a nedílnou součástí kapitalistického výrobního způsobu je skutečnost, že pozitivně i negativně, ve zdraví i nemoci, průmyslový způsob produkce potravin ovlivňuje lidské tělo. Po vstupu lidské společnosti do éry moderny a postmoderny ale osudová smyčka, spjatá s průmyslovou výrobou potravin a masovou distribucí jídla, stále více svírá lidská těla, která pod vlivem médií a reklamy oscilují mezi sklony k obezitě, bulimii nebo destruktiv- ní cukrovce. Boj o jídlo, stejně jako život s nadbytkem potravin, se stále více podobá čtyřem jezdcům $z$ apokalypsy. První jezdec, jedoucí na bílém koni, hrozí svým lukem, že po období přebytků přijde smrtonosný dobyvatel, jehož jméno je mor a šíření dalších infekčních onemocnění. Druhý jezdec se řítí na ohnivém koni a ve svých rukou svírá moc, která mu umožňuje odejmout lidem mír a ve jménu boje o zdroje potravin vyhlásit válku všech proti všem. Třetí jezdec, který si osedlal černého koně, drží v ruce váhy a hlásá směrem k obyvatelům hladovějících rozvojových zemí biblické: „Za denní mzdu jen mírka pšenice...". Poselství tohoto jezdce lze vyjádřit jediným slovem: hladomor. Čtvrtý jezdec, přijiždějící na sivém koni, je symbolem smrti, která se ohlíží na lidmi zpustošenou planetu a při zamyšlení nad člověkem smutně konstatuje „a svět mrtvých zůstal za ním..... (Bible 1995).

Člověk je „vyvolený primát“, nebot” v průběhu svého evolučního vývoje vytvořil nový adaptační mechanismus - kulturu, jejímž prostřednictvím postupně začal přetvářet vnější svět i svojí vlastní přirozenost. $\mathrm{Na}$ jedné straně jsme i nadále součástí přírody a naše těla formují biologické faktory, jako jsou přírodní výběr, tělesný stav organismu, endokrinní systém, látková výměna nebo genetická výbava. Na straně druhé naší biologickou podstatu a naše těla ovlivňuje kultura vystupující $\mathrm{v}$ podobě uměle vytvořeného prostředí, naučených vzorců chování a symbolických systémů. Z této perspektivy je člověk paradoxně bipolární bytost stále více evokující osud „padlého anděla“.

\section{LITERATURA}

Ariès, Philippe (2000): Dějiny smrti. Praha: Argo.

Barkow, Jerome H. - Cosmides, Leda - Tooby, John (eds.). (1992): The Adapted Mind: Evolutionary Psychology and the Generation of Culture. New York: Oxford University Press.

Barker, Graeme (2006): The Agricultural Revolution in Prehistory: Why Did Foragers Become Farmers? Oxford: Oxford University Press.

Barloewen, Constantin von (1996): Der Tot in den Weltkulturen und Weltreligionen. München: Diederichs Verlag.

Bible. (1995): Praha: Česká biblická společnost.

Brieger, G. H. (2004): Bodies and Borders: A New Cultural History of Medicine. Perspectives in Biology and Medicine, 43(3), 402-421.

Brown, Peter - Closser, Svea (ed.). (2016): Understanding and Applying Medical Anthropology. London: Routledge.

Conrad, Peter - Schneider, Joseph (1980): Deviance and medicalization: From Badness to Sickness. St. Louis: Mosby.

Diamond, Jared (2000): Osudy lidských společností: Střelné zbraně, choroboplodné zárodky a ocel v historii. Praha: Columbus.

Ember, Carol R. - Ember, Melvin, (eds.). (2004): Encyclopedia of Medical Anthropology: Health and Illness in the World's Cultures. New York: Kluwer Academic/Plenum Publishers.

Evans, Dylan - Zarate, Oscar (2002): Evoluční psychologie. Praha: Portál.

Evans-Pritchard, Edward E. (1937): Witchcraft, Oracles and Magic among the Azande. Oxford: Clarendon Press.

Foster, George M. - Gallatin Anderson, Barbara (1978): Medical Anthropology. New York: John Wiley and Sons.

Gennep, Arnold van (1997): Přechodové rituály: Systematické studium rituálio. Praha: Nakladatelství Lidové noviny.

Good, Byron (1994): Medicine, Rationality and Experience: An Anthropological Perspective. New York: Cambridge University Press,

Good, Byron (1977): The Heart of What's the Matter: The Semantics of Illness in Iran. Culture, Medicine and Psychiatry 1, 25-58. 
Hahn, Robert (ed.) (1999): Anthropology in Public Health. Bridging Differences in Culture and Society. New York, Oxford: Oxford University Press.

Harari, Yuval N. (2013): Sapiens: Od zviřete k božskému jedinci. Praha: LEDA. Heidegger, Martin (2002): Bytí a čas. Praha: OIKOYMENH.

Helman, Cecil (2001): Culture, Health and Illness. London: Arnold.

Henke, Winfried - Tattersall, Ian (2007): Handbook of Paleoanthropology. Vol I.: Principles, Methods and Approaches. Heidelberg, Berlin: Springer.

Hrešanová, Ema (2008): Medicínská antropologie a její aplikace. In: Hirt, T. a kol. Vybrané kapitoly z aplikované sociální antropologie. Plzeň: Západočeská univerzita v Plzni, 211-236.

Illich, Ivan (1976): Medical Nemesis: The Expropriation of Health. New York: Pantheon Books.

Joralemon, Donald (2017): Exploring Medical Anthropology. London: Taylor \& Francis Books Ltd.

Kleinman, Arthur - Eisenberg, Leon - Good, Byron J. (1978): Culture, Illness and Care. Annals of Internal Medicine 88, 251-258.

Kleinman, Arthur (2020): The Illness Narratives: Suffering, Healing, And the Human Condition. New York: Basic Books.

Kottak, Conrad (2007): Mirror for Humanity. A Concise Introduction to Cultural Anthropology. Boston: McGrawHill.

Kottak, Conrad (2018): Anthropology: Appreciating Human Diversity. New York: McGraw-Hill Education.

Lévi-Strauss, Claude (1971): Myšlení př́rodních národů. Praha: Československý spisovatel.

Lieberman, Daniel E. (2016): Př́iběh lidského těla. Praha: Jan Melvil Publishing.

Levinson, David - Ember, Melvin (eds). (2008): Encyclopedia of Cultural Anthropology. New York: Henry Holt and Co.

Lockwood, Charles (2008): The Human Story: Where We Come from \& How We Evolved. New York: Sterling.

Lupton, Deborah (1994): Medicine as Culture. Illness, Disease and the Body in Western Societies. London: Sage.

Miller, Barbara - Wood, Bernard (2006): Anthropology. Boston: Pearson Education.

Mühlpachr, Pavel (2009): Gerontopedagogika. Brno: Masarykova univerzita.

Nettleton, Sarah (2006): Sociology of Health and Illness. Cambridge: Polity Press.

Olver, Ian N. - Robotin, Monica C. (2012): Perspectives on Complementary and Alternative Medicines. London: Imperial College Press.

Pike, Kenneth Lee (1967): Language in Relation to a Unified Theory of the Structure of Human Behavior. The Hague: Mouton.
Pyšný, Ladislav (2002): Fyziologie a patofyziologie dopingu. Praha: Univerzita Karlova v Praze.

Porter, Roy (2002): Největší dobrodiní lidstva: Historie medicíny od starověku po součastnost. Praha: Prostor.

Scherer, Georg (2005): Smrt jako filosofický problém. Kostelní Vydří: Karmelitánské nakladatelství.

Simmons, Alan H. (2011): The Neolithic Revolution in the Near East: Transforming the Human Landscape. Tucson: University of Arizona Press.

Singer, Merrill (1995): Beyond the Ivory Tower: Critical Praxis in Medical Anthropology. Medical Anthropology Quarterly 9 (1), 80-106.

Singer, Merrill - Baer, Hans (eds.). (2011): Introducing Medical Anthropology: A Discipline in Action. New York: AltaMira Press.

Singer, Merrill - Baer, Hans (2018): Critical Medical Anthropology. Boca Ranton: CRC Press.

Singer, Merrill - Baer, Hans - Long, Debbi - Pavlotski, Alex (2019): Introducing Medical Anthropology: A Discipline in Action. Lanham: The Rowman \& Littlefield Publishing Group, Inc.

Singer, Merrill - Erickson, Pamela I. (ed.). (2015): A Companion to Medical Anthropology. New York: John Wiley \& Sons.

Sígl, Miroslav (2006): Co víme o smrti. Praha: Epocha.

Soukup, Václav (2011): Antropologie: Teorie člověka a kultury. Praha: Portál.

Soukup, Václav (2015): Prehistorie rodu Homo. Praha: Karolinum.

Soukup, Václav (2016): Smrt jako biologická konstanta a kulturní konstrukce: Př́spěvek k antropologii smrti. In: Gabašová, Katarína - Jakubovská Kristina - Maiello, Giuseppe (ed.). (De)tabuizácia smrti vo filozofickoantropologickou diskurze. Nitra: Univerzita Konštantína Filozofa, 81-108.

Susman, Randall L. - Stern, Jack T. (1983): The Locomotor Behavior of Australopithecus afarensis. American Journal of Physical Anthropology 60, 279-317.

Svoboda, Jiří A. (2014): Předkové: Evoluce člověka. Praha: Academia.

Turner, Bryan (1995): Medical Power and Social Knowledge. London: SAGE.

Turner, Victor (1969): The Ritual Process: Structure and Anti-structure. Chicago: Aldine.

Waldstein, Anna - Adams, Cameron (2006): The Interface between Medical Anthropology and Medical Ethnobiology. Journal of the Royal Anthropological Institute 12, 95-117.

Wiley, Andrea S. - Allen, John, S. (Eds.). (2016): Medical Anthropology: A Biocultural Approach. Oxford: Oxford University Press.

Winkelman, Micheal (2009): Culture and Health: Applying Medical Anthropology. San Francisco: Jossey-Bass.

Winston, Robert (ed.). (2005): Člověk. Praha: Knižní klub. 